\title{
Carbon flows in the benthic food web of the Porcupine Abyssal Plain: The (un)importance of labile detritus in supporting microbial and faunal carbon demands
}

\author{
Dick van Oevelen, i,** Karline Soetaert, a and Carlo Heip b
}

\author{
a Department of Ecosystem Studies, Royal Netherlands Institute of Sea Research (NIOZ) (formerly: Netherlands Institute of Ecology, \\ NIOO-KNAW), Yerseke, The Netherlands \\ b Royal Netherlands Institute for Sea Research (NIOZ), Den Burg-Texel, The Netherlands
}

\begin{abstract}
Carbon flows in the benthic food web of the Porcupine Abyssal Plain (4850 m, northeast Atlantic) were reconstructed using linear inverse modeling based on mass balances of the various compartments, biomass data, carbon flux measurements, physiological constraints, and data from a previously published ${ }^{13} \mathrm{C}$-phytodetritus pulse-chase experiment. Food web compartments consisted of bacteria, Foraminifera, three feeding types of nematodes and of macrofauna, and four feeding types of megafauna. Three lability classes of detritus were defined to clarify especially the possible role of labile detritus in this abyssal plain food web. Total detritus inputs to the food web were $0.56 \mathrm{mmol} \mathrm{C} \mathrm{m} \mathrm{C}^{-2} \mathrm{~d}^{-1}$, with only a minor $(3.8 \%)$ contribution of labile detritus. The dominant pathway in the food web was dissolution of more refractory detritus, uptake by bacteria, and subsequent respiration $\left(0.36 \mathrm{mmol} \mathrm{C} \mathrm{m} \mathrm{m}^{-2} \mathrm{~d}^{-1}, 80 \%\right.$ of the community respiration). Lower contributions to community respiration were found for surface-deposit-feeding macrobenthos $(5.6 \%)$, Foraminifera $(4.9 \%)$, predatory macrobenthos $(3.8 \%)$, and other deposit-feeding macrobenthos $(3.1 \%)$. Contributions by other benthic compartments were $<1 \% .{ }^{13} \mathrm{C}$-phytodetritus transfer data strongly constrained the carbon source for bacteria, Foraminifera, and the nematode and macrobenthic compartments. Surprisingly, labile detritus contributed $<5 \%$ of the total carbon requirements for all these compartments. Carbon sources were much less constrained for the megabenthic compartments because for these compartments no ${ }^{13} \mathrm{C}$ pulse-chase data were available. The carbon flow model evidently shows a limited role of labile detritus in the food web.
\end{abstract}

Abyssal sediments at water depths between 3000 and $6000 \mathrm{~m}$, the majority of which consist of soft sediments, cover a vast $54 \%$ of the earth's surface (Smith et al. 2008). Except for chemosynthetic environments, such as vents and seeps, organisms inhabiting these soft sediments depend entirely on detritus delivery from the ocean's photic zone (Graf 1992; Smith et al. 2008). This becomes evident in the relation between water depth and benthic biomass: detritus input decreases with increasing water depth and induces a concomitant decrease in metazoan biomass (Smith et al. 2008; Wei et al. 2010). The coupling between the surface and the deep is further substantiated through evidence from time series in which temporal variation in surface productivity and export flux of detritus was linked to subsequent respiration and biomass response by deep-sea benthic communities (Ruhl et al. 2008; Smith et al. 2009). The magnitude of the response of the benthic community depends, however, not only on the amount of particulate organic carbon (POC) that is deposited on the seafloor, but also on its lability, composition, and accessibility.

Detritus is a mixture of compounds of different labilities and as it is incorporated in the sediment, it is diluted with a large stock of sedimentary detritus that has an even larger range in lability of up to six orders of magnitude (Middelburg and Meysman 2007). In general, the contribution of a detritus fraction to the total detritus pool is inversely related to its lability (Middelburg and Meysman 2007). Considering the differences in detritus lability and concentration in the sediment, responses may differ between

\footnotetext{
* Corresponding author: dick.van.oevelen@nioz.nl
}

benthic compartments that depend on different detritus fractions. Benthic biota relying primarily on a labile, and hence small, pool of detritus might be expected to react faster to a phytodetritus pulse. However, they may also suffer from food limitation during prolonged periods of time of low phytodetritus availability. In contrast, the biomass response of benthic biota that rely more on a less labile, and hence larger, pool of detritus will be weaker, but these organisms are also less subjected to food limitation because of the presence of a larger sedimentary detritus stock in the sediment.

Deciphering the dependence of benthic biota on different detritus fractions has been challenging because sampling these remote abyssal plain sediments has been hampered by technological and logistical difficulties, and so extensive data sets that cover the complete benthic community of abyssal plains are scarce. Sediment community oxygen consumption (SCOC) has been used as a measure of the response to labile phytodetritus input by the benthic community, thereby integrating all oxic and anoxic degradation pathways (Glud 2008). Temporal changes in SCOC in cold deep-sea sediments may be limited in magnitude (Smith and Kaufmann 1999) and short lived (Graf 1992). These results, combined with a lack of SCOC response after the addition of ${ }^{13} \mathrm{C}$-phytodetritus to various sediment cores led Moodley et al. (2005) to suggest that the natural deposition of phytodetritus is typically too low in magnitude to invoke a significant increase in the SCOC. On the other hand, SCOC dynamics at Sta. M (Northeast Pacific) showed a prominent seasonal signal, albeit damped in magnitude as compared to the variation in POC input 
(Smith et al. 2009). To reproduce these seasonal SCOC dynamics with a diagenetic model, two detritus pools with different reactivity were required (Soetaert et al. 1996). The model indicated clearly that the fast-degrading detritus fraction had a degradation rate of $0.027 \mathrm{~d}^{-1}$ and dominated the POC input $(70 \%)$, whereas the slow-degrading fraction had a degradation rate of $2.7 \times 10^{-5} \mathrm{~d}^{-1}$ and represented $30 \%$ of the input (Soetaert et al. 1996). This indicates that labile phytodetritus may form an important component of the total POC input.

Researchers have used different types of tracers to obtain insights into faunal feeding preferences. A preference for labile material has been inferred from the analyses of gut contents of deep-sea fauna for phytopigments (Witbaard et al. 2001; Wigham et al. 2008), Th ${ }^{234}$ activity (Demopoulos et al. 2003), protein content (Amaro et al. 2010), and organic matter content (Bock and Miller 1999). The rationale is that an elevated tracer concentration in the gut as compared to surrounding sediment indicates selective feeding. Another sensitive method is to add ${ }^{13} \mathrm{C}$-labeled phytodetritus to the benthic community in pulse-chase experiments. The uptake of ${ }^{13} \mathrm{C}$ by benthic fauna and bacteria and subsequent respiration allows tracing the fate of labile detritus through the benthic community (Blair et al. 1996; Moodley et al. 2002; Witte et al. 2003). Although these methods typically show selective feeding and ${ }^{13} \mathrm{C}$ tracer uptake by deep-sea fauna, it remains difficult to assess the role of different detritus pools in the total diet because the role of more refractory detritus in the diet is not quantified.

Linear inverse modeling is a data assimilation method that allows integrating carbon process and biomass data to quantify elemental flows in food webs (Vézina and Platt 1988; Van Oevelen et al. 2010) and has proved to be useful to infer carbon flows in benthic food webs (Eldridge and Jackson 1993; Van Oevelen et al. 2006). In most benthic food web studies, however, it is common to lump all types of detritus into one compartment, thus neglecting detritus quality differences (Rowe et al. 2008). But when the standard linear inverse model is extended with data from pulse chase ${ }^{13} \mathrm{C}$ experiments, in which the fate of labile detritus is followed (Van Oevelen et al. 2006), a finer resolution in the detritus pools can be achieved. This extended modeling methodology showed that the green (i.e., primary producers) and brown (i.e., detritus) pathways were clearly separated in an intertidal sediment, with the green pathway supporting primarily the metazoan compartments whereas the brown pathways supported primarily bacteria carbon demands (Van Oevelen et al. 2006). Gontikaki et al. (2011) applied the same strategy to data from a ${ }^{13} \mathrm{C}$ pulse-chase experiment in a continental slope sediment in the Faroe Shetland Channel (1080-m water depth) and showed the potential to also reconstruct deep-sea food webs. It appeared that labile detritus supported $<10 \%$ of the carbon demands of the faunal compartments in the benthic food web, while less labile detritus pools dominated faunal diets. This type of modeling has, however, not been applied in an abyssal plain setting.

The Porcupine Abyssal Plain (PAP) was one of the first deep-sea stations where seasonal deposition events of phytodetritus were discovered (Billett et al. 1983). This finding initiated several large-scale programs at this station and the study site has now been established as PAP Sustained Observatory with particular emphasis on export of particulate organic matter from the water column to the seafloor and responses by the benthic community, most notably holothurians (Lampitt et al. 2010a). An important feature at PAP is its seasonal and multi-annual dynamics with respect to phytodetritus deposition, which is strongly linked to the spring phytoplankton bloom in surface waters (Billett et al. 1983) and the response of the benthic community to seasonal and interannual supply of organic matter (Billett et al. 2001, 2010; Ruhl et al. 2008). It is not clear how important these phytodetritus pulses are in the total carbon budget of the PAP because data on carbon fluxes and benthic biomass have not been integrated at the food web level. Also, an in situ experimental ${ }^{13} \mathrm{C}$-phytodetritus addition has been performed at this site (Witte et al. 2003).

In this paper, we present a linear inverse modeling study of the PAP in which data on benthic biomass and total carbon processing are integrated with the results from the in situ experimental ${ }^{13} \mathrm{C}$-phytodetritus addition to obtain a picture of carbon flows in the benthic food web with special emphasis on the importance of labile detritus for the benthic community. As such, the integration of the isotope tracer experiment with a model of total carbon processing allows deciphering the importance and pathways of different detritus classes within an abyssal food web.

\section{Methods}

Study site and food web structure - The PAP lies southwest of Ireland (Northeast Atlantic) and is remote from continental slopes. The PAP site has a comparatively flat seabed at $4850-\mathrm{m}$ water depth and the sediment is a calcareous ooze with a mean grain size of $8-8.6 \mu \mathrm{m}$ (Billett and Rice 2001). The site has been studied in various European Union projects and is sustained as a multidisciplinary observatory in the North Atlantic (coordinated by the National Oceanography Centre, Southampton) such that considerable knowledge regarding fluxes and benthic community structure is available.

The food web at PAP is divided in several biotic and abiotic compartments with flows connecting the compartments within the food web and connecting compartments with the overlying water and deep sediment. The food web structure is largely identical to that defined for the Nazaré Canyon (Van Oevelen et al. 2011b) and the Arctic observatory Hausgarten (Van Oevelen et al. 2011a). To account for the variation in quantity and quality, the detritus pool is divided into three operationally defined particulate pools: labile detritus (carbon that can be linked to chlorophyll $a$ ); semi-labile detritus (carbon linked to the biopolymers lipids, proteins, and carbohydrates); and refractory detritus (the remaining uncharacterized detritus). Dissolved organic carbon (DOC) completes the abiotic compartments. The benthic community is divided into the classical size-based compartments bacteria, Foraminifera, nematodes, macrobenthos, and megabenthos. Since information regarding feeding types is available for the nematodes and the macro- and megabenthos, these were further subdivided. The nematodes are divided using the 
feeding classification based on nematode mouth morphology (Wieser 1953) into selective feeders (types $1 \mathrm{~A}+2 \mathrm{~A}$, because both feeding types feed selectively on, e.g., bacteria and diatoms), nonselective feeders (type 1B), and omnivores + predators (type $2 \mathrm{~B}$ ). The macro- and megabenthos are divided into surface-deposit feeders, deposit feeders, suspension feeders, and predators + scavengers.

The inputs to the food web are detritus deposition from the water column and feeding on labile and semi-labile detritus in the water column by suspension-feeding macro- and megabenthos. Refractory detritus can be removed from the food web through deep burial. DOC can efflux from the sediment to the water column and also dissolved inorganic carbon that is produced through respiration effluxes to the water column. Secondary production by the macro- and megabenthic compartments that is not consumed within the modeled food web is treated as export (e.g., consumption by fish).

Flows within the food web comprise feeding on labile and semi-labile detritus by Foraminifera, nematode compartments, and non-suspension-feeding macrobenthic and megabenthic compartments. Bacteria are consumed by all non-suspension-feeding benthic fauna compartments, Foraminifera and non-predatory nematode compartments are consumed by predatory + omnivore nematodes, and non-suspension-feeding macrobenthos and megabenthos. Predatory + omnivore nematodes are consumed by nonsuspension-feeding macrobenthic and megabenthic compartments, all non-predatory macro- and megabenthic compartments are preyed upon by predatory macrobenthos and megabenthos. Finally, the predatory macrobenthos is preyed upon by predatory megabenthos.

Part of the ingested carbon by Foraminifera, nematodes, macrobenthos, and megabenthos is not assimilated but lost as feces. Feces produced from ingested semi-labile detritus consist of refractory detritus; semi-labile detritus is produced upon defecation of the other carbon sources. The assimilated carbon is partly respired, to account for maintenance and growth respiration, and the remainder is used for secondary production. Faunal mortality is represented as a flow from the faunal compartments to labile detritus. Hydrolysis of the three detritus compartments induces a flow to the DOC compartment. Bacteria assimilate DOC for respiration and biomass production. Viral lysis of bacteria is implemented as a flux from bacteria to DOC.

Data availability-The data on carbon stocks and process rates that are implemented in the model are described below and collected in Tables 1 and 2 .

The labile detritus pool of $1.4 \mathrm{mmol} \mathrm{C} \mathrm{m}^{-2}$ is calculated by converting the average sedimentary chlorophyll $a$ (Chl a) pool (Witbaard et al. 2000) to carbon equivalents assuming a $\mathrm{C}: \mathrm{Chl} a$ ratio of 40 that is representative of living phytoplankton (following Stephens et al. 1997). Similarly, the deposition of labile detritus as estimated from Chl $a$ deposition in contrasting seasons using short-term sediment trap deployments, ranged from 0.0010 to $0.0227 \mathrm{mmol} \mathrm{C} \mathrm{m} \mathrm{C}^{-1}$ (Witbaard et al. 2000). The degradation rate of labile detritus, including both dissolution and fauna grazing, is constrained to be within the minimum $\left(0.004 \mathrm{~d}^{-1}\right)$ and maximum $\left(0.15 \mathrm{~d}^{-1}\right)$ Chl $a$ degradation rate reported by Witbaard et al. (2000). The degradation rates calculated directly by dividing the range in labile detritus fluxes by its stock gives a range of $0.0007-$ $0.016 \mathrm{~d}^{-1}$. This range is consistent with, but at the lower end of the $0.004-0.15 \mathrm{~d}^{-1}$ range reported by Witbaard et al. (2000), indicating internal consistency of the data. Semilabile detritus is defined as the sum of carbon equivalents of carbohydrates, amino acids, and lipids (i.e., the biopolymerics in Danovaro et al. 2001), from which the labile detritus pool is subtracted and amounts to $1940 \mathrm{mmol} \mathrm{C}$ $\mathrm{m}^{-2}$. Deposition of semi-labile is the summed deposition of carbohydrates and proteins (both representing $>90 \%$ of the biopolymerics, Danovaro et al. 2001) and ranges between 0.03 and $0.26 \mathrm{mmol} \mathrm{C} \mathrm{m}^{-2} \mathrm{~d}^{-1}$ (Fabiano et al. 2001). Refractory detritus is defined as the total organic carbon stock (OC\% of $0.45 \mathrm{wt} \%$ and porosity of 0.80 , Witbaard et al. 2000; Ståhl et al. 2004), from which the labile and semi-labile detritus pool is subtracted and amounts to $7621 \mathrm{mmol} \mathrm{C} \mathrm{m}{ }^{-2}$. Detritus respiration by the benthic community was estimated from SCOC measurements and converted to carbon equivalents using a respiration quotient of 1 (Glud 2008), averaging $0.45 \mathrm{mmol}$ $C \mathrm{~m}^{-2} \mathrm{~d}^{-1}$ (Witbaard et al. 2000). This value corresponds well to carbon oxidation measurements $(0.46 \pm 0.37 \mathrm{mmol}$ $\mathrm{C} \mathrm{m}^{-2} \mathrm{~d}^{-1}$, Ståhl et al. 2004) and the background SCOC of $0.44 \pm 0.04 \mathrm{mmol} \mathrm{O}_{2} \mathrm{~m}^{-2} \mathrm{~d}^{-1}$ found by Witte et al. (2003). The burial flux of detritus is estimated at $0.03 \mathrm{mmol} \mathrm{C}$ $\mathrm{m}^{-2} \mathrm{~d}^{-1}$ from sediment accumulation and OC\% below the mixed layer in the sediment (Ståhl et al. 2004). The efflux of DOC inferred from concentration gradients between the sediment and bottom water ranged between 0.05 and $0.08 \mathrm{mmol} \mathrm{C} \mathrm{m}^{-2} \mathrm{~d}^{-1}$ and the DOC stock was $18.6 \mathrm{mmol} \mathrm{C}$ $\mathrm{m}^{-2}$ (Lahajnar et al. 2005).

Biomass values for the benthic community (Table 1) were taken from various studies. Bacterial biomass was $10.8 \mathrm{mmol}$ $\mathrm{C} \mathrm{m}^{-2}$, and bacterial production ranged between 0.015 and $0.040 \mathrm{mmol} \mathrm{C} \mathrm{m} \mathrm{m}^{-2} \mathrm{~d}^{-1}$ (Eardly et al. 2001). The meio- and macrobenthic samples from the high-resolution temporal and spatial study of the BENthic biology and Geochemistry of a north-eastern Atlantic abyssal Locality (BENGAL) research program were only published as abundances (Galéron et al. 2001), from which it is not possible to infer biomass values and therefore other data resources were used. Meiobenthos was divided into nematodes (the numerically dominant metazoan group, Galéron et al. 2001) with a biomass of $0.9 \mathrm{mmol} \mathrm{C} \mathrm{m}^{-2}$ (averaged from Heip et al. 2001 and Witte et al. 2003). The division of the nematode community by Sebastian et al. (2007) in the Wieser classes (Wieser 1953) was used to partition nematode biomass among the feeding types (see above for definitions). Foraminifera were reported to have a biomass of $1.3 \mathrm{mmol}$ $\mathrm{C} \mathrm{m}^{-2}$ (Witte et al. 2003). Data on macrobenthos were used from Aberle and Witte (2003), which corresponds reasonably with results from an earlier study nearby: $9.1 \mathrm{mmol} \mathrm{C} \mathrm{m}-2$ (Aberle and Witte 2003) vs. $13.2 \mathrm{mmol} \mathrm{C} \mathrm{m}^{-2}$ (Flach et al. 2002). Specialized literature (Fauchald and Jumars 1979) and results from the feeding classification based on stable isotope data by Iken et al. (2001) were used to partition the biomass data into feeding modes (Table 1). Billett et al. (2001) sampled the biomass of the megabenthic community 
Table 1. Stocks (mmol $\mathrm{C} \mathrm{m}^{-2}$ ) of the food web compartments at the PAP. Abbreviation gives the compartment abbreviation that is used throughout the figures. Depth $(\mathrm{cm})$ is the sampling depth for which the stock is calculated. Period is the sampling period over which the stock value is determined. See "Data availability" for details and references.

\begin{tabular}{lllc}
\hline \hline \multicolumn{1}{c}{ Compartment } & Abbreviation & Depth & Period \\
\hline Labile detritus & Det & $0-5$ & Stock \\
Semi-labile detritus & sDet & $0-5$ & $1997-$ Sep 1998 \\
Refractory detritus & rDet & $0-5$ & Sep 1996-Oct 1998 \\
Dissolved organic carbon & DOC & Jul 1996-May 1999 & 1940 \\
Bacteria & Bac & $0-5$ & Oct 1996-May 2000 \\
Foraminifera & For & $0-5$ & Jul 1997-Sep 1998 \\
Selective-feeding nematodes & NemSF & $0-10$ & May 2000-Jun 2000 \\
Non-selective-feeding nematodes & NemNF & $0-15$ & Oct 1993-Jun 2000 \\
Predatory + omnivore nematodes & NemPO & $0-15$ & Oct 1993-Jun 2000 \\
Macrobenthic surface deposit feeders & MacSDF & $0-15$ & Oct 1993-Jun 2000 \\
Macrobenthic deposit feeders & MacDF & $0-10$ & May 2000-Jun 2000 \\
Macrobenthic predators + scavengers & MacPS & $0-10$ & May 2000-Jun 2000 \\
Megabenthic surface-deposit feeders & MegSDF & $0-10$ & May 2000-Jun 2000 \\
Megabenthic deposit feeders & MegDF & Trawl & 0.82 \\
Megabenthic predators + scavengers & MegPS & Trawl & Sep 1996-Oct 1998 \\
\hline
\end{tabular}

repeatedly at PAP. The wet weight data were converted to carbon units using conversion factors from Rowe (1983) and corrected for a $40 \%$ loss of wet weight of holothurians due to fixation (Billett et al. 2001), which gives a total megabenthic biomass of $0.62 \mathrm{mmol} \mathrm{C} \mathrm{m}^{-2}$. Iken et al. (2001) divided the holothurians into three different groups. Group A comprises smaller opportunistic superficial sediment-feeding species such as Amperima rosea, group B contains larger superficial feeders that nevertheless seem to feed on older organic matter due to a lower mobility as compared to group A, and group $\mathrm{C}$ are the subsurface-deposit feeders that are less mobile and also feed on older organic matter. Group A was assigned as a surface-deposit feeder and groups B and C were grouped into deposit feeders because both groups feed on older organic matter. The other megabenthic taxonomic groups were assigned to feeding types using specialized literature.

Both the deposit- and surface-deposit-feeding holothurians ingest organic matter with higher than the ambient Chl $a$ and total hydrolyzable amino acid content (Ginger et al. 2001; Witbaard et al. 2001; Wigham et al. 2003), suggesting that they selectively feed on organic matter of higher quality. However, the selectivity of the surfacedeposit feeders is stronger than that of the deposit feeders
(Wigham et al. 2003). To accommodate this selectivity in the model, selective ingestion of labile detritus over semilabile detritus was defined as the ratio of Chl a concentrations in gut with respect to the ambient surface sediment (Witbaard et al. 2001; Wigham et al. 2003). Nonselective feeding implies feeding on labile detritus and semi-labile detritus in proportion to their respective stock ratio. The Chl $a$ content in the guts of the mobile surface-deposit feeder $A$. rosea (Wigham et al. 2003) was between 525 and 781 times higher than in the sediment (sedimentary chlorophyll data from Witbaard et al. 2000), suggesting strong selectivity for labile detritus. The Chl $a$ content in guts of other holothurians, classified as deposit feeders, was between 2 and 18 times higher as compared to the sedimentary Chl $a$ content (Ginger et al. 2001; Wigham et al. 2003, 2008). Since species other than $A$. rosea are also in the surface-deposit-feeding group, selectivity for surfacedeposit feeding was broadened to 50-1000 and selectivity for deposit feeders was set to 1-50 (Table 2). Since similar information on selectivity is not available for the nematode and macrobenthic feeding types, and therefore the constraints of the megabenthos were also used for these latter compartments (Table 2).

Table 2. Data from site-specific measurements that are implemented in the model as range [minimum, maximum] or as single value. Period is the sampling period from which the value is determined. See "Data availability" for details and references.

\begin{tabular}{|c|c|c|}
\hline Process description & Period & Value \\
\hline Deposition of labile detritus ( $\mathrm{mmol} \mathrm{C} \mathrm{m}^{-2} \mathrm{~d}^{-1}$ ) & Sep 1996-Sep 1998 & {$[0.0010,0.0227]$} \\
\hline Degradation rate of labile detritus $\left(\mathrm{d}^{-1}\right)$ & Sep 1996-Sep 1998 & {$[0.004,0.15]$} \\
\hline Deposition of semi-labile detritus (mmol $\mathrm{C} \mathrm{m}^{-2} \mathrm{~d}^{-1}$ ) & Sep $1996-$ Sep 1998 & {$[0.03,0.26]$} \\
\hline Total carbon mineralization $\left(\mathrm{mmol} \mathrm{C} \mathrm{m}^{-2} \mathrm{~d}^{-1}\right.$ ) & Sep 1996-Sep 1998 & 0.45 \\
\hline Efflux of DOC from sediment (mmol $\mathrm{C} \mathrm{m}^{-2} \mathrm{~d}^{-1}$ ) & Oct 1996-May 2000 & {$[0.05,0.08]$} \\
\hline Burial of organic carbon $\left(\mathrm{mmol} \mathrm{C} \mathrm{m}^{-2} \mathrm{~d}^{-1}\right)$ & Sep 1996-Sep 1998 & 0.03 \\
\hline Bacterial production ( $\mathrm{mmol} \mathrm{C} \mathrm{m}^{-2} \mathrm{~d}^{-1}$ ) & Sep 1996-Mar 1998 & {$[0.015,0.04]$} \\
\hline Selectivity MeiSF, MacSDF, and MegSDF* & & {$[50,1000]$} \\
\hline Selectivity MeiNSF, MacDF, and MegDF* & & {$[1,50]$} \\
\hline
\end{tabular}

* Selectivity is defined as $\frac{\text { ingested labile carbon } / \text { total ingested carbon }}{\sum \text { labile carbon stocks/ } / \sum \text { carbon stocks }}$ and is 1 when food sources are consumed in their stock proportion. See Table 1 for 
Table 3. Equality and inequality constraints on processes implemented in the food web model of the PAP. The last constraints are marked with an asterisk because they are added in the fitting step to improve the model fit with ${ }^{13} \mathrm{C}$ tracer data (see additional information in Methods, Results, and Discussion). Values designated as single number imply that the data are implemented as equality, and values designated as [minimum, maximum] and are implemented as inequalities. For, Foraminifera; Nem, nematodes; Mac, macrobenthos; Meg, megabenthos.

\begin{tabular}{|c|c|c|}
\hline Inequality description & Unit & Value \\
\hline Degradation rate of rDet + & $d^{-1}$ & {$\left[2.27 \times 10^{-6}, 8.22 \times 10^{-4}\right]$} \\
\hline Bacterial growth efficiency & - & {$[0.05,0.45]$} \\
\hline Viral lysis of bacterial production & - & {$[0.40,1.00]$} \\
\hline Temperature limitation (Tlim) & - & $0.30\left(2.6^{\circ} \mathrm{C}\right)$ \\
\hline Faunal maintenance respiration & $\mathrm{mmol} \mathrm{C} \mathrm{m-2} \mathrm{d}^{-1}$ & Tlim $\times 0.01 \times$ stock \\
\hline Assimilation efficiency of labile sources For and Nem† & - & {$[0.57,0.77]$} \\
\hline Assimilation efficiency of semi-labile detritus For and Nem§ & - & {$[0.29,0.39]$} \\
\hline Net growth efficiency Foraminifera & - & {$[0.30,0.50]$} \\
\hline Production rate Foraminifera & $d^{-1}$ & Tlim $\times[0.03,0.09]$ \\
\hline Mortality rate Foraminiferall & $d^{-1}$ & $\operatorname{Tlim} \times[0,0.09]$ \\
\hline Net growth efficiency nematodes & - & {$[0.60,0.90]$} \\
\hline Production rate nematodes & $\mathrm{d}^{-1}$ & Tlim $\times[0.05,0.20]$ \\
\hline Mortality rate nematodes & $\mathrm{d}^{-1}$ & $\operatorname{Tlim} \times[0,0.20]$ \\
\hline Assimilation efficiency of labile sources Mac and Megł̦ & - & {$[0.40,0.75]$} \\
\hline Assimilation efficiency of semi-labile detritus Mac and Meg§ & - & {$[0.20,0.38]$} \\
\hline Net growth efficiency Mac and Meg§ & - & {$[0.50,0.70]$} \\
\hline Production rate Mac & $\mathrm{d}^{-1}$ & Tlim $\times[0.01,0.05]$ \\
\hline Mortality rate Mac & $\mathrm{d}^{-1}$ & Tlim $\times[0,0.05]$ \\
\hline Production rate Meg & $\mathrm{d}^{-1}$ & $\operatorname{Tlim} \times[0.0027,0.0137]$ \\
\hline Mortality rate $\mathrm{Meg}$ & $d^{-1}$ & $\operatorname{Tlim} \times[0,0.0137]$ \\
\hline Feeding preference NemPO, MacPS, and MegPS\# & - & {$[0.75,1.00]$} \\
\hline Burial efficiency & - & {$[0.004,0.10]$} \\
\hline DOC efflux from sediment relative to total POC input & - & {$[0,0.10]$} \\
\hline Labile detritus dissolution* & $\mathrm{mmol} \mathrm{C} \mathrm{m} \mathrm{m}^{-2} \mathrm{~d}^{-1}$ & {$[0.02,0.05]$} \\
\hline Bacterial growth efficiency* & - & {$[0,0.15]$} \\
\hline Fraction labile detritus in diet Foraminifera* & - & {$[0.01,0.05]$} \\
\hline Fraction labile detritus in diet selective-feeding nematodes* & - & {$[0,0.005]$} \\
\hline Fraction labile detritus in diet non-selective-feeding nematodes* & - & {$[0,0.005]$} \\
\hline Fraction labile detritus in diet surface-deposit-feeding macrofauna* & - & {$[0,0.02]$} \\
\hline
\end{tabular}

* Constraint added in the fitting step.
$\dagger$ Degradation rate is defined as outflows from detritus compartment $j$ divided by its carbon stock: $\frac{\sum_{k} x_{j \rightarrow k}}{C_{j}}$.

$\ddagger$ Assimilation efficiency of labile sources is defined as the fraction of all ingested labile sources ( $i$. with $i \neq$ semi-labile detritus) being assimilated: $\frac{\sum_{i} x_{i \rightarrow j}-x_{j \rightarrow \mathrm{s} \text { DeI }}}{\sum_{i} x_{i \rightarrow j}}$

$\S$ Assimilation efficiency of semi-labile is defined as the fraction of ingested semi-labile detritus being assimilated: $\frac{x_{\mathrm{sDet} \rightarrow j}-x_{j \rightarrow \mathrm{rDet}}}{x_{\mathrm{sDet} \rightarrow j}}$.

I| The mortality and production rates are biomass specific.

ๆ Net growth efficiency is defined as: $\frac{\sum_{i} x_{i \rightarrow j}-x_{i \rightarrow \text { detritus }}-\left(x_{j \rightarrow D I C}-\text { maintenance respiration }\right)}{\sum_{i} x_{i \rightarrow j}-x_{j \rightarrow \text { detritus }}}$.

\# The feeding preference here is defined as fraction of total ingested met by predation. See Table 1 for full compartment names.

In addition to these site-specific data, a number of constraints were taken from the literature to further constrain carbon flows in the food web. Degradation rates of refractory detritus, bacterial growth efficiency, assimilation efficiency of Foraminifera, net growth efficiency of all faunal compartments, and production and mortality rates of all faunal compartments were constrained (Table 3 ). The degradation rate of the refractory pool was constrained between $2.3 \times$ $10^{-6}$ and $8.2 \times 10^{-4} \mathrm{~d}^{-1}$, which encompasses the degradation rates of organic matter in abyssal plain sediments (Epping et al. 2002) and refractory compounds (Henrichs and Doyle 1986). The bacterial growth efficiency is constrained between 0.05 and 0.45 (Del Giorgio and Cole 1998). Viral infection induces bacterial mortality in deep-sea sediments and in the model between $40 \%$ and $100 \%$ of the bacterial production undergoes morality due to viral lysis (Middelboe and Glud 2006; Danovaro et al. 2008). Respiration rates, assimilation efficiencies, growth efficiencies, and production rates are rarely collected for deep-sea fauna; therefore, we decided to use an extensive literature review (Van Oevelen et al. 2006) of temperate benthos as basis for some constraints. For the higher trophic levels, respiration is partitioned between maintenance respiration and growth respiration. Maintenance respiration of all faunal compartments was defined as $0.01 \mathrm{~d}^{-1}$ at $20^{\circ} \mathrm{C}$ (Van Oevelen et al. 2006) and is corrected with a temperature limitation factor (Tlim) based on the $\mathrm{Q}_{10}$ formulation with a doubling of rates for every $10^{\circ} \mathrm{C}$ increase in temperature. Bottom-water temperature at PAP is $2.6^{\circ} \mathrm{C}$ (Hall et al. 2007). Net growth efficiencies were constrained based on Van Oevelen et al. (2006) and Hendriks (1999). 
The assimilation efficiency was made dependent on the lability of the carbon source. Labile sources were assumed to be assimilated with higher efficiency $(57-77 \%$ for Foraminifera and nematodes, $40-75 \%$ for macro- and megabenthos, based on Van Oevelen et al. 2006). The assimilation efficiency of semi-labile detritus was assumed to be lower by a factor of 2 (29-39\% for Foraminifera and nematodes, 20 $38 \%$ for macro- and megabenthos). These ranges match reasonably well with the assimilation efficiency of total organic matter for deposit-feeding holothurians, ranging between $15 \%$ and $22 \%$ at the Bay of Biscay (Khripounoff and Sibuet 1980) and between $16 \%$ to $46 \%$ at the PAP (Ginger et al. 2001). Production rates were constrained for Foraminifera, nematodes, and macrobenthos based on Van Oevelen et al. (2006), but were corrected for the low temperature with the $\mathrm{Q}_{10}$ formulation. Megabenthic production rates were constrained using Ruhl (2007). The feeding preference for the predatory + omnivore nematodes (NemPO) and predatory + scavenging macro- and megabenthic compartments (MacPS and MegPS) was set to a minimum of $75 \%$ predatory feeding to allow for omnivory in these feeding types. Burial efficiency is positively related to the accumulation rate of the sediment (Burdige 2006). Using the accumulation rate of $\sim 0.004 \mathrm{~g} \mathrm{~cm}^{-2} \mathrm{yr}^{-1}\left(6.1 \mathrm{~cm} \mathrm{k.y.}{ }^{-1}\right.$ and a dry bulk density of $0.74 \mathrm{~g} \mathrm{~cm}^{-3}$; Ståhl et al. 2004), the accumulation rate is $\sim 0.004 \mathrm{~g} \mathrm{~cm}^{-2} \mathrm{yr}^{-1}$. This translates into a range for burial efficiency from $0.4 \%$ to $10 \%$. DOC efflux from the sediment is correlated with the total OC input to the sediment (Burdige et al. 1999) and is typically $<10 \%$ for continental margin sediments, which was used as upper limit here. This constraint was compatible with the measured DOC effluxes by Lahajnar et al. (2005), which indicates internal consistency of the data.

Linear inverse modeling methodology-The food web model developed here is constructed using linear inverse modeling. A linear inverse model (LIM) is used to find numerical values for the flows that are a priori defined for the food web under the condition that these numerical values must be consistent with the imposed equality and inequality data constraints. As such, a LIM produces a portrayal of carbon flows within the food web.

Several reviews on linear inverse modeling have been published recently and contain simple models that demonstrate the setup and solution of LIMs (Soetaert and Van Oevelen 2009; Van Oevelen et al. 2010). To facilitate the application of LIMs by a broader audience, the LIM package (Van Oevelen et al. 2010) is written in the free software R ( $R$ Development Core Team 2011), which allows the easy setup and solving of LIMs. Because of the substantial background information that is now available, we limit here our methodological discussion on LIMs to its essentials.

A LIM is formed by two matrix equations:

$$
\begin{gathered}
\text { Equality equation: } \mathbf{A x}=\mathbf{b} \\
\text { Inequality equation: } \mathbf{G x}>=\mathbf{h}
\end{gathered}
$$

in which vector $\mathbf{x}$ contains the unknown flows (i.e., $x_{i} \ldots x_{n}$ ). Each row in the equality Eq. 1 imposes a strict constraint: a linear combination of flows must match the corresponding value in vector $\mathbf{b}$. This equation contains a mass balance for each compartment and the data equalities (Table 2). The inequality Eq. 2 imposes lower and upper bounds on flows or on linear combinations of flows. A default set of inequalities is the condition $\mathbf{x} \geq 0$, which ensures that flows have directions that are consistent with the imposed food web topology. Equation 2 also holds the data inequalities in Tables 2 and 3. In all, the default food web model of the PAP has 138 carbon flows, 17 mass balances (i.e., compartments), 2 data equalities, and 145 data inequalities.

Although a substantial amount of data is implemented in the model, the number of unknown flows (138) outnumbers the data equations in the LIM $(17+2)$, a typical situation in LIMs (Van Oevelen et al. 2010). This mathematical underdeterminacy implies that an infinitely large set of solutions can be found that is consistent with the matrix equations. Rather than aiming for one unique solution, we follow a recently developed likelihood approach (Van Oevelen et al. $2010)$ in which a large set of different solutions $(25,000$ in this case) is sampled from the infinite number of solutions. Each sampled solution represents a different food web configuration that is consistent with the matrix Eqs. 1, 2. The mean and standard deviation for each food web flow is calculated from this set of sampled solutions and represents a central estimate (i.e., the mean) of the flow value and its associated uncertainty (i.e., standard deviation) (Van Oevelen et al. 2010). The set of 25,000 solutions is large enough to ensure convergence on the estimation of the mean and standard deviation (Van Oevelen et al. 2011b).

Dynamic tracer model - Witte et al. (2003) monitored the response of the benthic community at PAP to a phytodetritus deposition event using a ${ }^{13} \mathrm{C}$ pulse chase experiment. Briefly, the diatom Thalassiosira rotula was grown in the laboratory in ${ }^{13} \mathrm{C}$-bicarbonate-enriched medium, freezedried, and subsequently injected into incubation chambers that were placed at the seafloor. Incubation chambers were incubated for $2.5,8$, and $23 \mathrm{~d}$ before being brought to the surface and sampled for respiration of ${ }^{13} \mathrm{C}$ and incorporation into different benthic compartments. The data from the ${ }^{13} \mathrm{C}$ tracer experiment cannot be implemented directly in the LIM matrix equations. Nevertheless, these data provide direct quantitative information on the transfer of phytodetritus, i.e., the labile detritus compartment in the LIM, in the food web. In order to take advantage of these data, the LIM was coupled with a dynamic tracer model (Van Oevelen et al. 2006). In short, the stock sizes and fluxes between the stocks define the rate at which a tracer disperses through the food web. Hence, linking the stock values (Table 1) with the LIM solution (i.e., carbon flow values) in a dynamic model allows making quantitative predictions on the transfer of labile detritus in the food web. These dynamic model predictions can be compared with the experimental data that were obtained by Witte et al. (2003). The likelihood approach described above generated a set of 25,000 different solutions. The solutions were fed one by one to the dynamic model and individually contrasted against the experimental data to identify the LIM solution that best reproduced the experimental data. 
The dynamic model is based on rate parameters that are calculated from the LIM output. Two types of interactions are distinguished: source based and source-sink based. The rate parameters that are source based are marked with $\lambda$ in Table 4 and are calculated as $\lambda_{a \rightarrow b}=f_{a \rightarrow b} / C_{a}$, in which $f_{a \rightarrow b}$ is the flow value of compartment $a$ to $b$ and $C_{a}$ is the carbon stock of the source compartment $a$. The rate parameters that are source-sink interactions, are marked $\theta$ in Table 4 and are calculated as $\theta_{a \rightarrow b}=f_{a \rightarrow b} /\left(C_{a} \cdot C_{b}\right)$, in which $C_{b}$ is the carbon stock of compartment $b$. These rate parameters are used to calculate the carbon flow between compartments when the stocks in the food web are perturbed such as with the pulse deposition of ${ }^{13} \mathrm{C}$-phytodetritus. Further, dimensionless parameters are $l A E_{\text {Fau }}$, the assimilation efficiency of labile carbon sources of the respective faunal compartment; $s A E_{F a u}$, the assimilation efficiency of semi-labile detritus of the respective faunal compartment; $N G E_{\text {Fau }}$, the net growth efficiency of a faunal compartment; and $B G E$ the bacterial growth efficiency, $\rho_{\text {Fau }}$ is the biomass-specific maintenance respiration rate of a faunal compartment $\left(\mathrm{d}^{-1}\right)$. The rate and physiological parameters are inferred for each LIM solution prior to the dynamic simulation. Full equations of the dynamic model are in Table 4.

The tracer model was initialized by mimicking the ${ }^{13} \mathrm{C}$ phytodetritus deposition $\left(1 \mathrm{~g} \mathrm{C} \mathrm{m}^{-2}\right.$, Witte et al. 2003) to the labile detritus compartment by setting the total stock of labile detritus to $83.3 \mathrm{mmol} \mathrm{C} \mathrm{m}^{-2}$ and the ${ }^{13} \mathrm{C}$ stock of labile detritus to $81.7 \mathrm{mmol}^{13} \mathrm{C} \mathrm{m}^{-2}$ (since the algal enrichment was 98 atom $\%{ }^{13} \mathrm{C}$ ). The square experimental chambers had a surface of $0.04 \mathrm{~m}^{-2}$, which was too small to include megafauna in this experiment (Witte et al. 2003). The biomass of the megafauna was therefore fixed to zero in the dynamic models such that their influence on processing phytodetritus and food web dynamics was omitted from the simulation. The dynamic model was solved for 25 simulation days in the $\mathrm{R}$ environment with the vode integration routine that is available in the deSolve package (Soetaert et al. 2010). The model cost, i.e., a measure for the goodness of fit, was calculated with the modCost function in the Flexible Modeling Environment package in R (Soetaert and Petzoldt 2010), using the standard deviation as a weighting factor for each data point. If the standard deviation was not available from the raw data, the observed incorporation value was used as weighting factor. Total computing time on a modern personal computer is $\sim 2 \mathrm{~d}$ for sampling the set of 25,000 LIM solutions and another $2 \mathrm{~d}$ to evaluate the goodness of fit of each solution with the dynamic tracer model.

Fitting the isotope tracer data - The data from the ${ }^{13} \mathrm{C}$ phytodetritus experiment are shown with the best-fit solution in Fig. 1 (dashed lines). Although ${ }^{13} \mathrm{C}$ respiration and SCOC are well reproduced by this default model (Fig. 1E,F), the model underestimates ${ }^{13} \mathrm{C}$ uptake by bacteria and strongly overestimates ${ }^{13} \mathrm{C}$ uptake by Foraminifera, nematodes, and macrofauna (Fig. 1A-D).

The LIM has 138 unknown flows and although 25,000 solutions is a large solution set, this may be insufficient to acquire a sufficient number of solutions, especially in the corners of the solution space (Soetaert and Van Oevelen
2009). These sampling problems may be partly responsible for the poor fit of some of the data. In the next step, therefore, we tried to steer the sampling of the solution space to improve the model fit with the ${ }^{13} \mathrm{C}$ data by adding extra constraints to the default model. After multiple tests and modifications, a limited set of extra constraints was added to improve the model fit (asterisk-marked constraints in the last rows of Table 3): (1) dissolution of labile detritus was increased to elevate ${ }^{13} \mathrm{C}$ incorporation by bacteria; (2) bacterial growth efficiency was lowered to increase bacterial respiration of ${ }^{13} \mathrm{C}$; and (3) diet contributions of Foraminifera, selective-feeding nematodes, nonselective-feeding nematodes, and surface-deposit-feeding macrobenthos was reduced to limit ${ }^{13} \mathrm{C}$ uptake by these faunal compartments. It is important to note that these additional constraints did not conflict with the default set of constraints; they merely narrowed the set of solutions to those that give a better fit to the data. After adding these additional constraints, another 25,000 different solutions were generated and contrasted against the ${ }^{13} \mathrm{C}$-phytodetritus experiment using the dynamic model. The LIM solution that best fitted the data was selected as final model solution (solid line in Fig. 1). The uncertainty associated with the final solution was quantified by calculating the minimum (min) and maximum $(\max )$ flow values in the best $10 \%$ of the model solutions (Van Oevelen et al. 2006; Gontikaki et al. 2011), which is the set of solutions that is selected from the other solutions (Fig. 2).

\section{Results}

Linear inverse model and model fits-The complete modeling methodology presented here consists of five stages. In the first stage, the default linear inverse model is developed based on data on stocks of detritus and biotic compartments, process rates, and literature constraints. In the second stage, 25,000 different solutions of this "default LIM" are evaluated against the results of an isotope tracer experiment. A third stage was added because the best default solution did not give a satisfactory fit with the isotope tracer data (Fig. 1). In this third stage, a small set of constraints was added to the default LIM to increase the chance of selecting a model solution that better agrees with the available data. This model is called "fitted LIM." It is important to note that the fitted LIM is simply a subset of the default LIM, but the subset was steered as to optimize the model against the isotope tracer data. In the fourth stage, again 25,000 different solutions of the fitted LIM were drawn and contrasted against the isotope tracer data as to select the final best model solution. In the fifth and final stage, the uncertainty of the final best model solution was assessed by selecting the best 10\% solutions of the fitted LIM to represent uncertainty of the fitted solution.

The best-fit solution of the 25,000 default LIM solutions did not give a satisfactory model fit for all components and processes in the food web, especially for ${ }^{13} \mathrm{C}$ uptake by bacteria, Foraminifera, nematodes, and macrofauna (Fig. 1). The additional constraints considerably improved the fit of the experimental data (Fig. 1), with the weighted sum of squared residuals (i.e., model cost) decreasing from 74,145 (default LIM) to 804 (fitted LIM) (Fig. 3). 
Table 4. Equations of the dynamic tracer model, in which $C_{a}$ is the carbon stock of compartment $a\left(\mathrm{mmol} \mathrm{C} \mathrm{m}^{-2}\right),{ }^{13} C_{a}$ is the excess ${ }^{13} \mathrm{C}$ tracer in compartment $a\left(\mathrm{mmol}{ }^{13} \mathrm{C} \mathrm{m}^{-2}\right), F a u$ indicates all Fauna compartments, $F_{a}$ is the fraction of excess ${ }^{13} \mathrm{C}$ tracer in compartment $a\left({ }^{13} \mathrm{C}: \mathrm{C}\right)$ and $f_{a \rightarrow b}$ indicates the flow value from compartment $a$ to $b$. See "Dynamic tracer model" for an explanation of the rate parameters $\lambda$ and $\theta$ and the physiological parameters $l A E_{F(u,}, s A E_{F(u,}, N G E_{F u}, B G E, \rho_{F u t u}$, and see Table 1 for abbreviation of compartment names. For clarity, each term in the differential equations has been given a brief explanation below.

Comp Differential equation

1Det

$$
\begin{aligned}
& \frac{d C_{l D e t}}{d t}=\underbrace{f_{l D e t+1 t \rightarrow l D e t}}_{\text {deposition }}+\underbrace{\sum_{F a u} \lambda_{F a u t \rightarrow D e t} C_{F a u}}_{\text {Faunal mortality }}-\underbrace{\lambda_{I D e t \rightarrow D O C} \cdot C_{I D e t}}_{\text {dissolution }}-\underbrace{\sum_{F a u} \theta_{l D e t \rightarrow F a t} \cdot C_{l D e t} \cdot C_{F a t}}_{\text {Faunal ingestion }} \\
& \frac{d^{13} C_{l D e t}}{d t}=\underbrace{\sum_{F u l} \lambda_{F a u \rightarrow l D e t} \cdot C_{F u u} \cdot F_{F u u}}_{\text {faunal mortality }}-\underbrace{\lambda_{l D e t \rightarrow D O C} \cdot C_{l D e t} \cdot F_{l D e t}}_{\text {detritus dissolution }}-\underbrace{\sum_{F u u} \theta_{l D e t \rightarrow F(u t} \cdot C_{l D e t} \cdot C_{F a u} \cdot F_{l D e t}}_{\text {faunal ingestion }}
\end{aligned}
$$

sDet

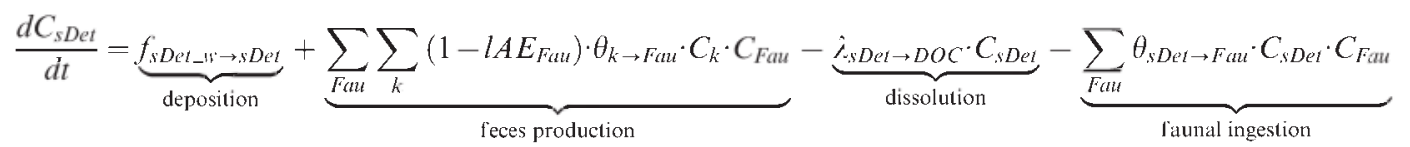

$$
\begin{aligned}
& \frac{d^{13} C_{s D e t}}{d t}=\underbrace{\sum_{F a t} \sum_{k}\left(1-l A E_{F a t}\right) \cdot \theta_{k \rightarrow F(t u} \cdot C_{k} \cdot C_{F a u t} \cdot F_{k}}_{\text {feces production }}-\underbrace{\lambda_{s D e t \rightarrow D O C} \cdot C_{s D e t} \cdot F_{s D e t}}_{\text {dissolution }}-\underbrace{\sum_{F a t u} \theta_{s D e t \rightarrow F a u t} \cdot C_{s D e t} \cdot C_{F a u} \cdot F_{s D e t}}_{\text {faunal ingestion }}
\end{aligned}
$$

rDet

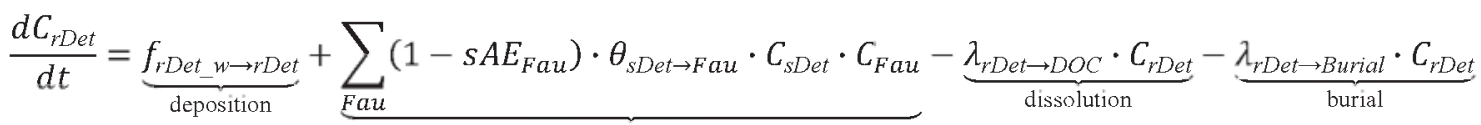

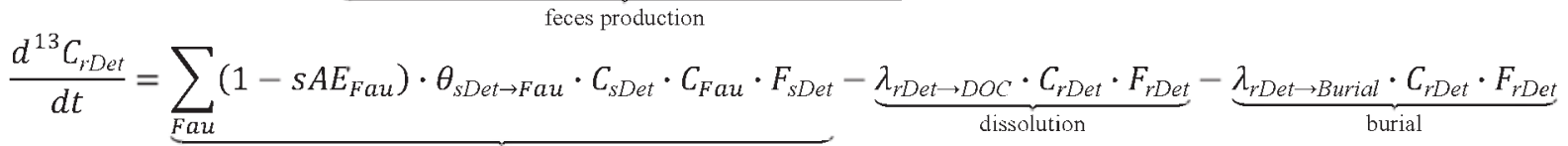

Bac

$$
\begin{aligned}
& \frac{d C_{B a c}}{d t}=\underbrace{\theta_{D O C \rightarrow B a c} \cdot C_{D O C} \cdot C_{B a c}}_{\text {DOC uptake }}-\underbrace{(1-B G E) \cdot \theta_{D O C \rightarrow B a c} \cdot C_{D O C} \cdot C_{B a c}}_{\text {respiration }}-\underbrace{\lambda_{B a c \rightarrow D O C} C_{B a c}}_{\text {mortality }}-\underbrace{\sum_{j} \theta_{B a c \rightarrow j} \cdot C_{B a c} \cdot C_{j}}_{\text {predation }}
\end{aligned}
$$

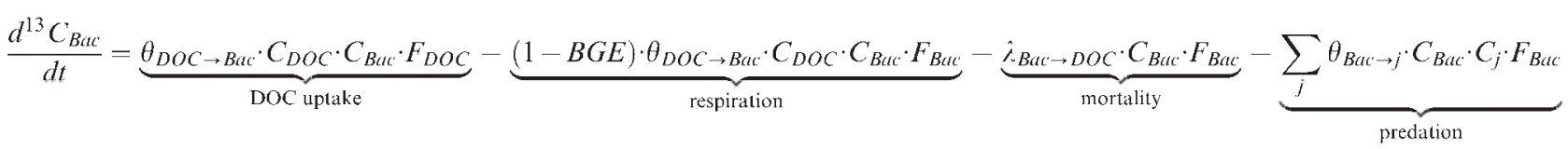

DOC

$$
\begin{aligned}
& \frac{d C_{D O C}}{d t}=\underbrace{\sum_{i} \lambda_{i \rightarrow D O C} C_{i}}_{\text {dissolution }}+\underbrace{\lambda_{B a c \rightarrow D O C} C_{B a c}}_{\text {bacterial mortality }}-\underbrace{\theta_{D O C \rightarrow B a \cdot} C_{D O C} \cdot C_{B a c}}_{\text {bacterial uptake }}-\underbrace{\lambda_{D O C \rightarrow D O C_{1}} \cdot C_{D O C}}_{\text {DOC efflux }} \\
& \frac{d^{13} C_{D O C}}{d t}=\underbrace{\sum_{i} \lambda_{i \rightarrow D O C} \cdot C_{i} \cdot F_{i}}_{\text {dissolution }}+\underbrace{\lambda_{B a C \rightarrow D O C} \cdot C_{B a C} \cdot F_{B a C}}_{\text {bacterial mortality }}-\underbrace{\theta_{D O C \rightarrow B a C} \cdot C_{D O C} \cdot C_{B a C} \cdot F_{D O C}}_{\text {bacterial uptake }}-\underbrace{\lambda_{D O C \rightarrow D O C_{11}} \cdot C_{D O C} \cdot F_{D O C}}_{\text {DOC efflux }}
\end{aligned}
$$


Table 4. Continued.

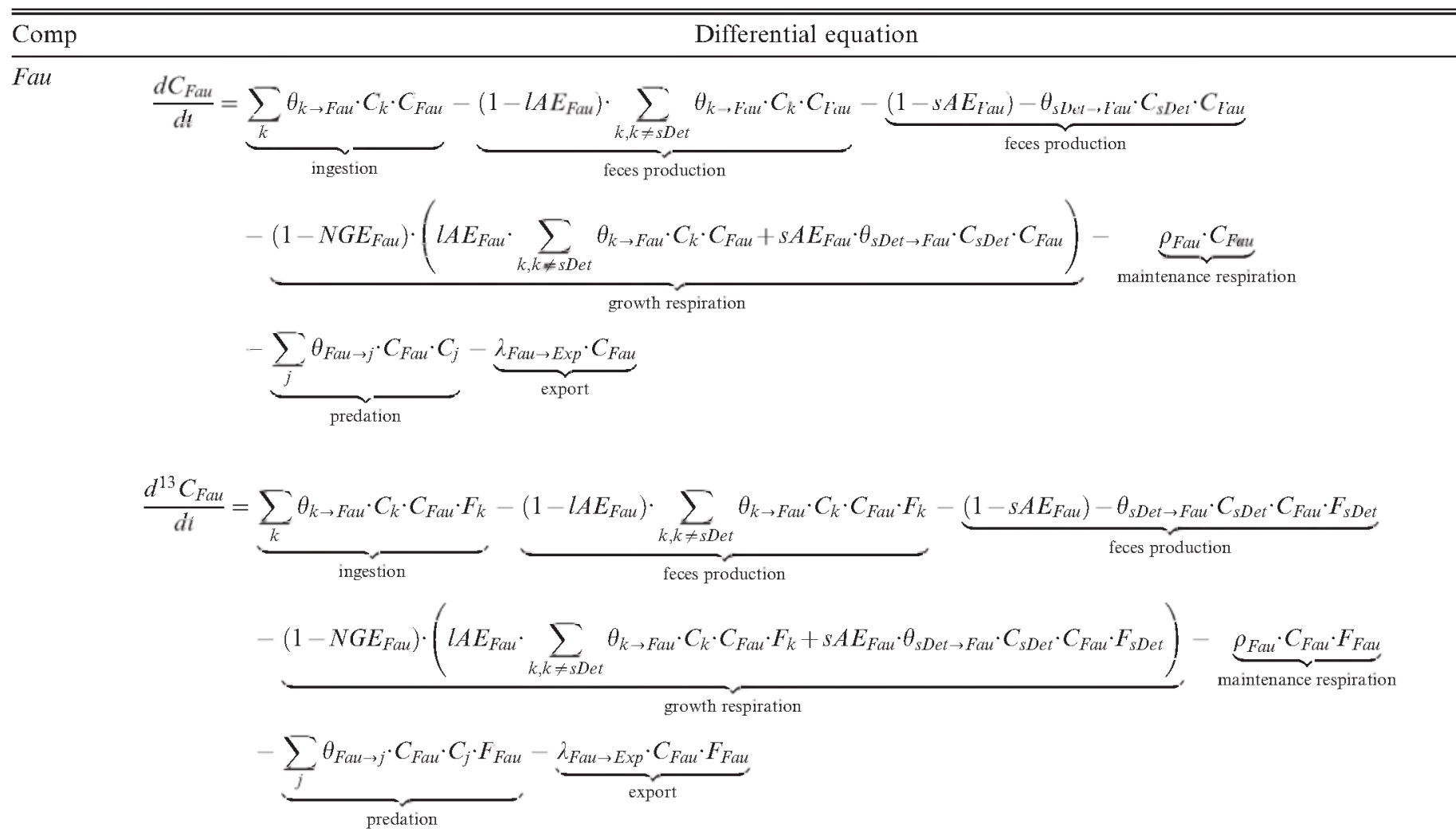

The simulation of the isotope tracer experiment that included the deposition of a large amount of ${ }^{13} \mathrm{C}$ phytodetritus and exclusion of megafauna from the experimental chambers invoked biomass changes in the other compartments of the food web. However, biomass changes of all biotic compartments remained within 74 $100 \%$ of their initial value during the $25 \mathrm{~d}$ of simulation time, except for predatory nematodes that decreased gradually to $12 \%$ of its initial value at day 25 . Such model instabilities and predator-prey oscillations are well-known characteristics of dynamic community models (May 1973; Gontikaki et al. 2011) and cannot be avoided. Since predatory nematodes comprise only a small fraction of the nematode biomass ( $1 \%$ at initial conditions), it is unlikely that these biomass fluctuations affect the results presented here.

Food web structure-In what follows, the carbon fluxes will be given as a "final solution" with the range [min of best $10 \%-\max$ of best $10 \%$ ] as indication of the uncertainty.

Total detritus input to the PAP food web is 0.56 [0.53$0.57] \mathrm{mmol} \mathrm{C} \mathrm{m} \mathrm{m}^{-2} \mathrm{~d}^{-1}$ and partitioned among labile $(3.8 \%$ [2.6-4.3\%]), semi-labile (43.1\% [31.8-49.0\%]), and refractory $(53.1 \%$ [46.9-64.2\%]) detritus. Losses from the food web sum to $0.56 \mathrm{mmol} \mathrm{C} \mathrm{m}^{-2} \mathrm{~d}^{-1}$ and are partitioned among community respiration $\left(0.45 \mathrm{mmol} C \mathrm{~m}^{-2} \mathrm{~d}^{-1}\right)$, DOC efflux $\left(0.07\right.$ [0.05-0.08] mmol $\left.\mathrm{C} \mathrm{m}^{-2} \mathrm{~d}^{-1}\right)$, burial
(0.03 mmol $\left.\mathrm{C} \mathrm{m}^{-2} \mathrm{~d}^{-1}\right)$, and export of secondary production (0.00151 [0.00017-0.00713] mmol $\left.\mathrm{C} \mathrm{m}^{-2} \mathrm{~d}^{-1}\right)$.

The dominant pathway within the PAP food web is dissolution of refractory detritus $(0.42[0.39-0.45] \mathrm{mmol} \mathrm{C}$ $\left.\mathrm{m}^{-2} \mathrm{~d}^{-1}\right)$, DOC uptake by bacteria $(0.39$ [0.37-0.42] $\mathrm{mmol}$ $\left.C \mathrm{~m}^{-2} \mathrm{~d}^{-1}\right)$, and subsequent bacterial respiration $(0.36$ [0.34-0.38] mmol C m $\mathrm{m}^{-2} \mathrm{~d}^{-1}$ ) (Fig. 4A). Semi-labile detritus uptake by surface-deposit- and deposit-feeding macrobenthos $(0.06$ [0.029-0.073] and 0.058 [0.023-0.064] mmol $\mathrm{C} \mathrm{m}^{-2} \mathrm{~d}^{-1}$, respectively) are almost an order of magnitude lower, similar to deposition of labile detritus and respiration by Foraminifera and macrobenthic compartments (Fig. 4B). Again of lower magnitude are the food web links between 0.005 and $0.05 \mathrm{mmol} \mathrm{C} \mathrm{m} \mathrm{m}^{-2} \mathrm{~d}^{-1}$ that includes mainly predation links by macrobenthic compartments and respiration by deposit-feeding megabenthos and selective- and nonselective-feeding nematodes (Fig. 4C). Finally, smallest flows between $1 \times 10^{-7}$ and $5 \times$ $10^{-4}$ are retained in Fig. 4D, which shows mortality flows together with predation flows by predatory nematodes, deposit-feeding macrobenthos, and megabenthos.

The community respiration $\left(0.45 \mathrm{mmol} \mathrm{C} \mathrm{m}^{-2} \mathrm{~d}^{-1}\right)$ is strongly dominated by bacteria $(80 \%)$ and has lower contributions from surface-deposit-feeding macrobenthos $(5.6 \%)$, Foraminifera $(4.9 \%)$, predatory macrobenthos $(3.8 \%)$, and deposit-feeding macrobenthos $(3.1 \%)$, contributions to total respiration by other benthic compartments 

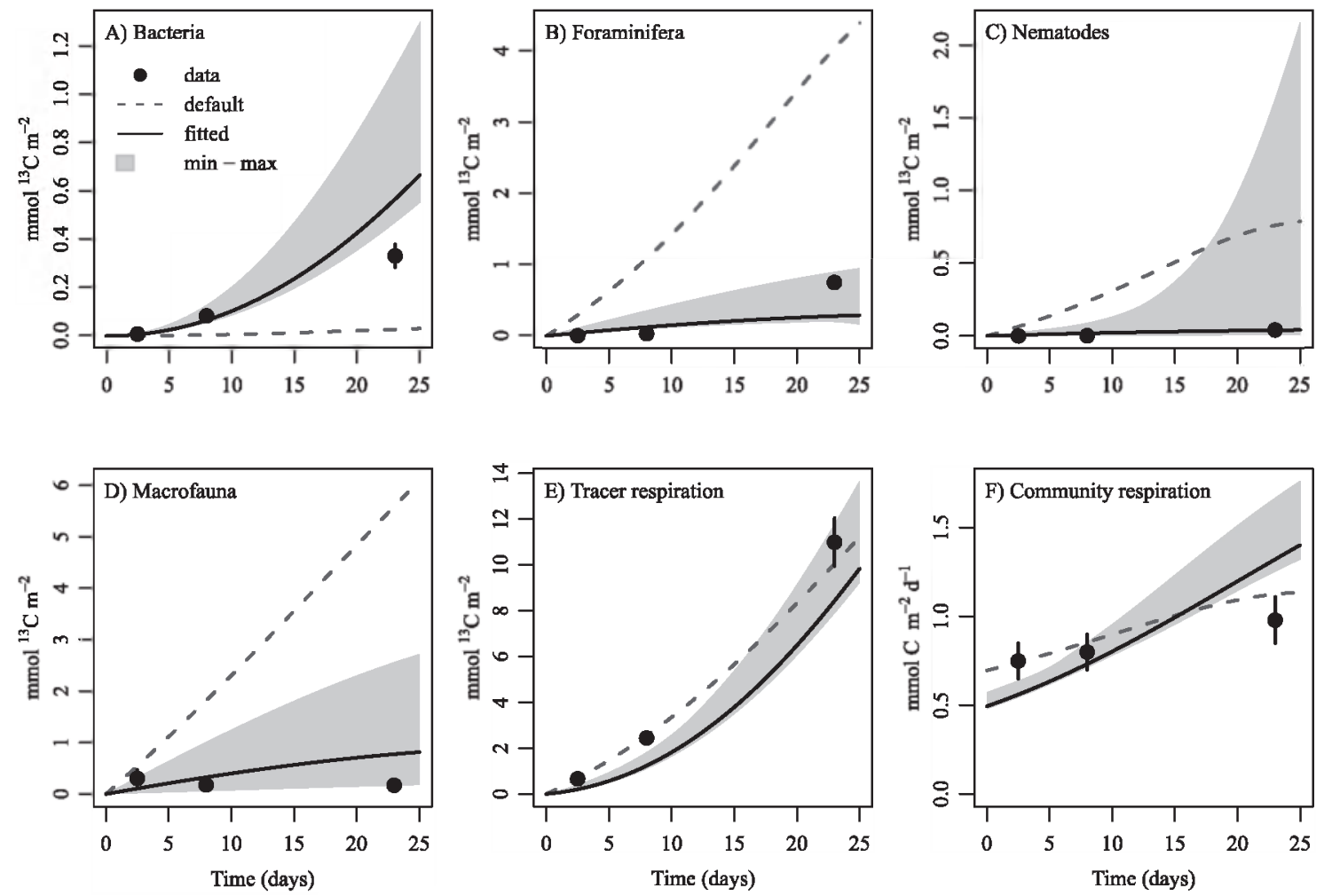

Fig. 1. Observed and modeled (A) ${ }^{13} \mathrm{C}$ in bacteria, (B) ${ }^{13} \mathrm{C}$ in Foraminifera, (C) ${ }^{13} \mathrm{C}$ in nematodes, i.e., sum of ${ }^{13} \mathrm{C}$ in $\mathrm{NemSF}$, NemNF, and NemPO, (D) ${ }^{13} \mathrm{C}$ in macrofauna, i.e., sum of MacSDF, MacDF, and MacPS, (E) cumulative respiration of ${ }^{13} \mathrm{C}$, and (F) sediment community respiration rates. Observed ${ }^{13} \mathrm{C}$ values are mean \pm standard deviation data from Witte et al. (2003). The lines represent the best-fit simulations of the "default LIM" (dashed) and "fitted LIM" (solid). The shaded area indicates the range in simulated variables of the best $10 \%$ of the fitted LIM as indication of uncertainty. Abbreviations: NemSF, selective-feeding nematodes; NemNF, non-selective-feeding nematodes; NemPO, predatory + omnivore nematodes; MacSDF, megabenthic surface-deposit feeders; MacDF, megabenthic deposit feeders; MacPS, macrobenthic predators + scavengers.

are $<1 \%$ (Table 5). Also total secondary production $\left(0.11 \mathrm{mmol} \mathrm{C} \mathrm{m}^{-2} \mathrm{~d}^{-1}\right)$ is dominated by bacteria $\left(0.028 \mathrm{mmol} \mathrm{C} \mathrm{m} \mathrm{m}^{-2} \mathrm{~d}^{-1}, 26 \%\right)$, but because of the higher growth efficiencies for the faunal compartments, their contributions are comparatively higher as compared to respiration contributions, with $22 \%$ for surface-depositfeeding macrobenthos $\left(0.024 \mathrm{mmol} \mathrm{C} \mathrm{m}^{-2} \mathrm{~d}^{-1}\right), 13 \%$ for Foraminifera $\left(0.014 \mathrm{mmol} \mathrm{C} \mathrm{m}^{-2} \mathrm{~d}^{-1}\right), 11 \%$ for depositfeeding and predatory macrobenthos, and $<10 \%$ for the other biotic compartments (Table 5). The export flux of $0.0015 \mathrm{mmol} \mathrm{C} \mathrm{m} \mathrm{m}^{-2} \mathrm{~d}^{-1}$ is dominated by surface-depositfeeding $(68 \%)$ and predatory $(14 \%)$ macrobenthos, respectively, with the other biotic compartments each contributing $<9 \%$.

The dominant carbon source for deposit-feeding compartments for which ${ }^{13} \mathrm{C}$ tracer data were available was semi-labile detritus (Fig. 5), with diet contributions ranging from $69 \%$ to $98 \%$ (NemNF and For, respectively), whereas labile detritus contributed only $<2 \%$ for each of these compartments. Our modeling exercise was done in part to obtain accurate estimates on the importance of labile detritus in the diets of benthic fauna, and it is clear that the addition of the ${ }^{13} \mathrm{C}$ tracer data significantly constrained these estimates (Fig. 6). This effect is, however, not seen for the megabenthic compartments, evidently because for these compartments there were no ${ }^{13} \mathrm{C}$ tracer data available. The contribution of labile detritus was higher for surfacedeposit- and deposit-feeding megabenthos as compared to the other benthic faunal compartments, but these estimates are less well constrained (Fig. 6). Bacteria contributed only marginally to the diets of most fauna $(<12 \%)$, but more for the selective and nonselective feeding nematodes $(23 \%$ and $31 \%$, respectively). Diet contributions are mixed for the predatory compartments, though dominated by nonselective feeding nematodes for the predatory nematodes $(64 \%)$ and by surface-deposit-feeding macrobenthos for predatory macrobenthos $(32 \%)$.

\section{Discussion}

Benthic communities in deep sediments are supported by organic detritus input that is ultimately derived from primary producers in the ocean's photic zone. Especially for abyssal plain sediments, it is still largely unknown how this detritus is processed and how important labile detritus is in supporting the different benthic food web compartments. One problem in quantifying the importance of labile detritus is to isolate the uptake of labile detritus from that of other, less labile detritus. With the combined linear inverse $+{ }^{13} \mathrm{C}$-phytodetritus isotope tracer modeling methodology employed here, it is possible to better resolve detritus processing by different benthic compartments and 

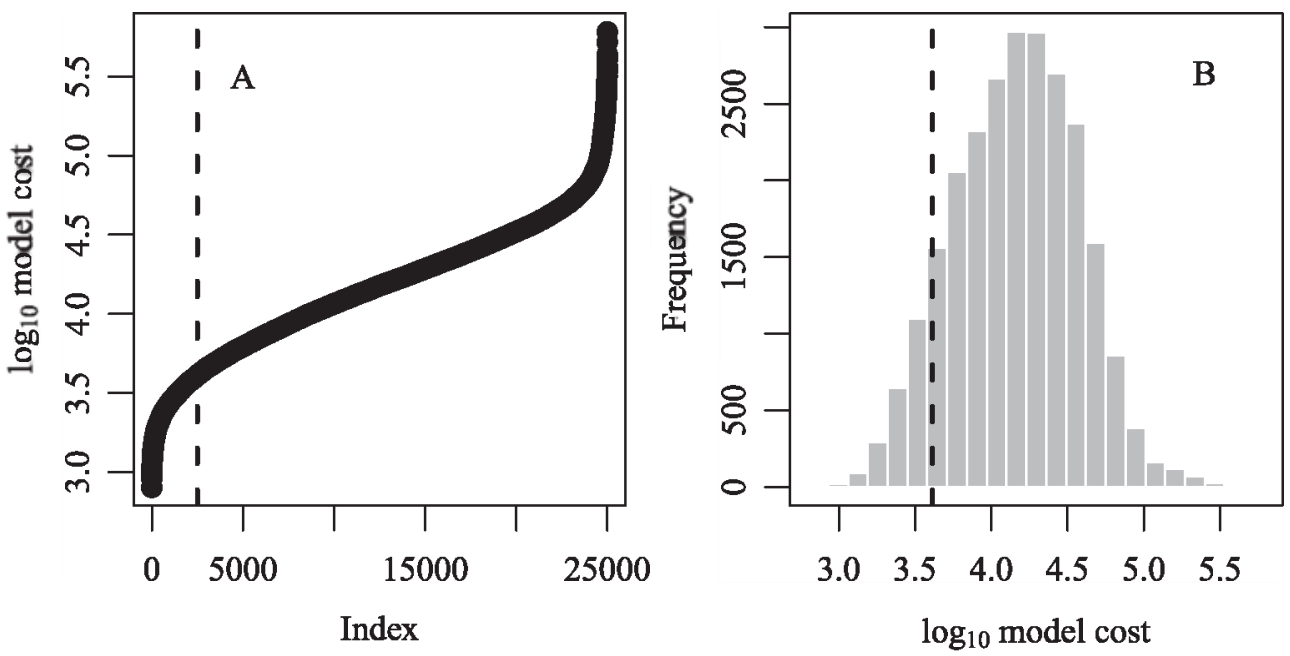

Fig. 2. (A) Sorted model cost values and (B) histogram of the model cost values of the "fitted LIM." The dashed lines indicate the cutoff of the best $10 \%$ of solutions that are used to infer the uncertainty, i.e., minimum and maximum flow value, on the fitted LIM.

to specifically quantify the role that labile detritus plays in the food web. Overall, it is shown that labile detritus is of only marginal importance for most biotic compartments in the food web of the PAP. Before discussing the implications and interpretation of our results, it is important to address the assumptions and limitations of the followed modeling approach, as these are the basis for this study.

Limitations of model and data-The conventional sizebased compartmentalization was used to define the food web compartments (Table 1 and Fig. 4). Additional

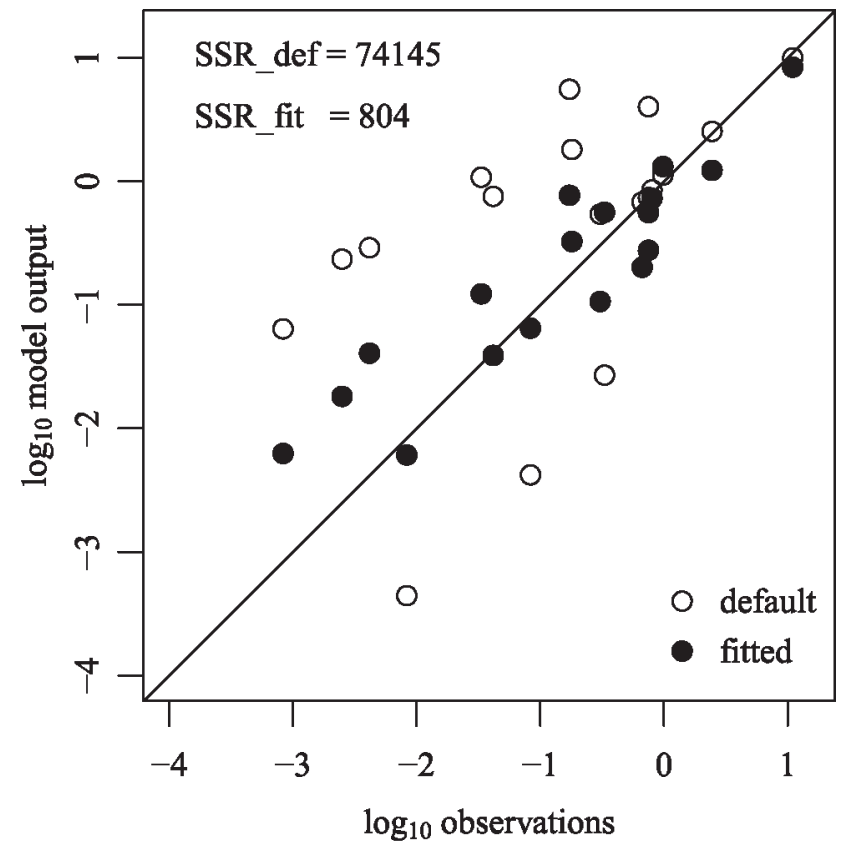

Fig. 3. Model predictions vs. experimental data from the ${ }^{13} \mathrm{C}$ isotope tracer experiment for the best solution of the "default LIM" and "fitted LIM." The SSR_def and SSR_fit indicated in the top left of the figure are the sum of squared residuals of the default LIM and fitted LIM, respectively. resolution was achieved by using information on feeding types to further split up the faunal compartments. As such, a resolution of 11 faunal compartments was achieved, which is high for deep-sea sediments (Heip et al. 2001; Rowe et al. 2008). This high compartment resolution naturally comes at a price because biomass values have to be defined for the different compartments and this is not straightforward. The nematode feeding classification is well established (Wieser 1953) and still used in many nematode studies (Sebastian et al. 2007). However, experimental evidence for feeding preferences is often lacking. Some macro- and megabenthic species can switch between suspension and deposit feeding (Fauchald and Jumars 1979), rendering classification difficult. Only a few suspension feeders occur at the PAP (Iken et al. 2001) and therefore suspension feeding is probably not an important feeding mode. Deposit feeders were split among surfacedeposit feeders and deposit feeders, with the former compartment feeding more selectivity on labile detritus as compared to semi-labile detritus, consistent with reports on the feeding strategies by the holothurians at PAP (Bett et al. 2001; Ginger et al. 2001; Wigham et al. 2003). Macroand megabenthos that are classified as carnivores are mostly omnivores rather than mere predators. To accommodate for this, feeding constraints were implemented that allowed predator feeding to range from omnivory $(25 \%$ feeding through non-predation) to $100 \%$ predation. Although the feeding classifications may not always be strict, they are successfully used in many papers to gain additional insight in the trophic structure of the benthic community (Flach et al. 1998), including the PAP (Iken et al. 2001), and there is much information on feeding by holothurians (Bett et al. 2001; Ginger et al. 2001; Wigham et al. 2003). This paper aimed to include specifically information on feeding types and isotope tracer studies to gain additional insights into the trophic structure of the benthic food web.

Another challenge was the definition of the detritus pools. In most benthic food web models, all detritus is lumped into one compartment for convenience (Rowe 

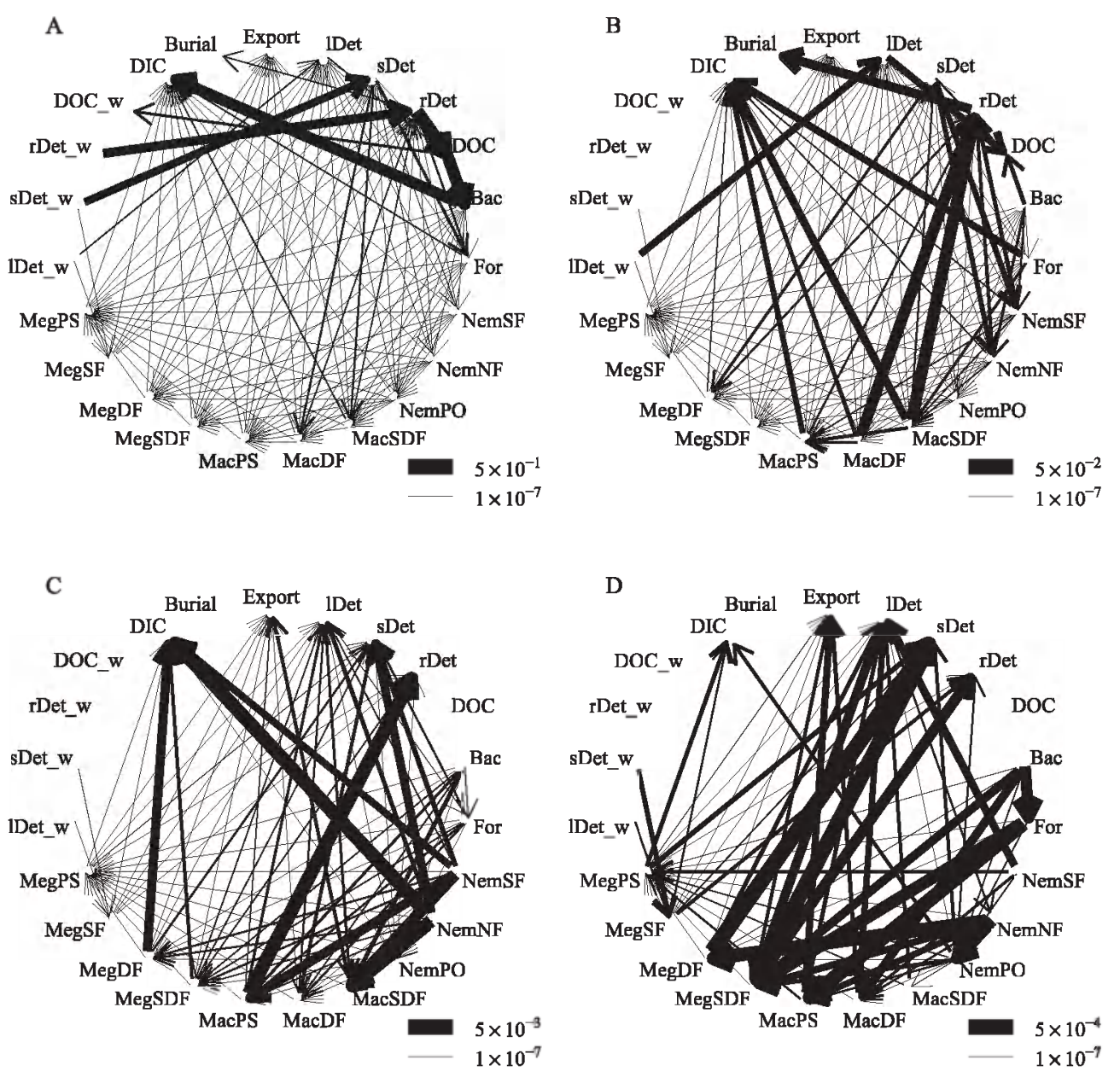

Fig. 4. Carbon flows among the food web compartments at the PAP. To better show the differences in carbon flows, the flows are scaled linearly to their magnitude according to the scale of the respective figure: (A) all carbon flows are shown, (B) only carbon flows $<$ $0.05 \mathrm{mmol} \mathrm{C} \mathrm{m}-2 \mathrm{~d}^{-1}$ are shown, (C) only carbon flows $<0.005 \mathrm{mmol} \mathrm{C} \mathrm{m} \mathrm{d}^{-2} \mathrm{~d}^{-1}$ are shown, and (D) only carbon flows $<0.0005 \mathrm{mmol}$ $C \mathrm{~m}^{-2} \mathrm{~d}^{-1}$ are shown. Abbreviations: IDet_w, labile detritus in the water column; sDet_w, semi-labile detritus in the water column; rDet_w, refractory detritus in the water column; DOC_w, dissolved organic carbon in the water column; DIC, dissolved inorganic carbon. See Table 1 for other compartment names.

et al. 2008), although it is well known that detritus degradation rates may vary over several orders of magnitude (Henrichs and Doyle 1986; Middelburg and Meysman 2007). The labile and refractory detritus compartments were most straightforward to define. Labile detritus input to deep marine sediments is commonly measured as Chl $a$ concentrations in sediment traps or the sediment surface, with high pigment fluxes and concentrations being related to the input of fresh and labile phytodetritus (Stephens et al. 1997; Witbaard et al. 2000). Chl $a$ therefore represents a natural choice to define the labile detritus compartment. Along this line, Stephens et al. (1997) converted Chl $a$ fluxes for an abyssal station to carbon units using a $\mathrm{C}: \mathrm{Chl} a$ ratio for living phytoplankton. A similar approach was followed here to convert the measured Chl $a$ fluxes and stock to define the labile detritus compartment. In addition, the organic carbon fraction in the sediment is a commonly used measure of total sedimentary detritus. Part of this detritus is recalcitrant and only degradable by bacteria (Benner et al. 1986; Deming and Baross 1993); hence, it is the total detritus minus the labile and semi-labile detritus that was defined refractory and this is not degradable by benthic fauna. The semi-labile detritus compartment was more difficult to define. There is a less labile detritus pool that is palatable for benthic fauna. The holothurian Molpadia musculus, for example, is believed to live head-down in the sediment and has no detectable pigment concentrations in its guts (Wigham et al. 2003). The current extraction and hydrolysis procedures allow characterizing only $20 \%$ to $40 \%$ of the total organic carbon in sediments as amino acids, carbohydrates, or lipids (Burdige 2006). This characterizable fraction of the total detritus pool is, in principle, available for assimilation by the fauna following hydrolyzation in the digestive tract. The extraction and hydrolyzation methods used for chemical characterization are usually harsher (e.g., lower $\mathrm{pH}$ and high temperatures) than those applied in a digestive tract (Mayer et al. 1995). However, the digestive environment between deposit-feeding organisms differs strongly (Mayer et al. 1997), such that it is difficult to determine the fraction of the chemically characterizable pool of detritus that is available to fauna. Therefore, the 


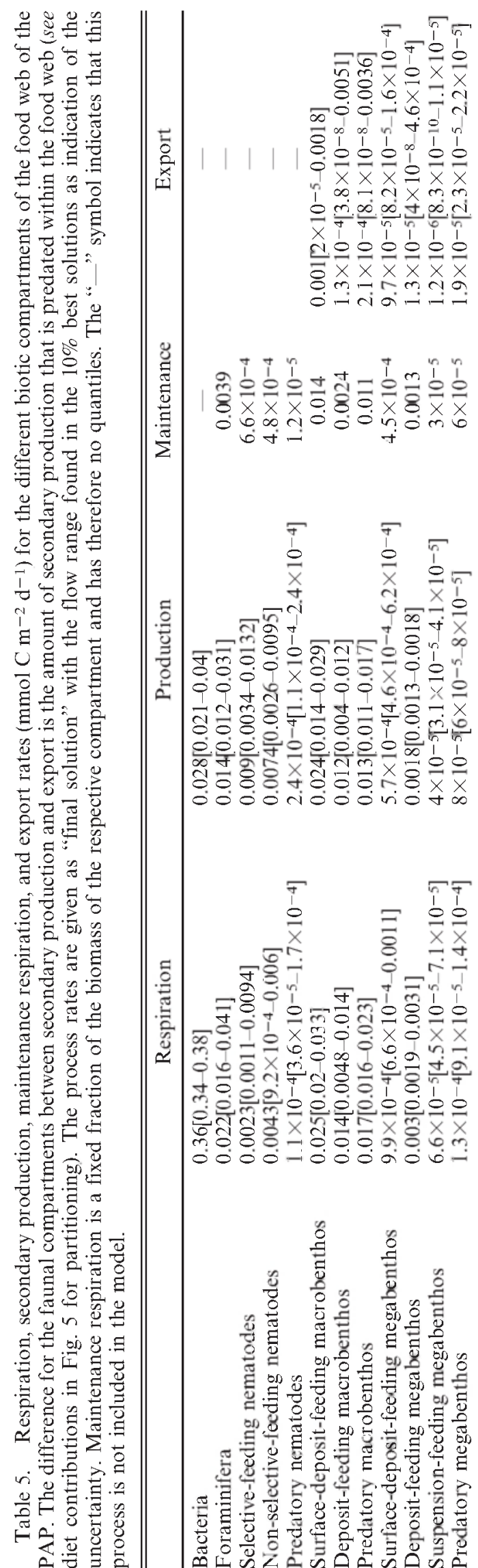

upper limit of the semi-labile detritus pool was defined as the sum of characterizable biopolymers (i.e., amino acids, lipids, and carbohydrates, Fabiano et al. 2001) as semilabile detritus, similarly as in a recent food web study of the Nazaré Canyon (Van Oevelen et a1. 2011b). We acknowledge that the proposed classification does not do full justice to the complexity of organic matter diagenesis. However, a close link between empirical data and different detritus compartments in the sediment was established and a reasonable distribution of the stock sizes of the detritus compartments was achieved, with labile detritus having a small stock size and refractory detritus a large stock size (Table 1), similar to field observations (Middelburg and Meysman 2007).

The food web presented here is based on a comprehensive data set that is unprecedented for abyssal plain sediments, consisting of carbon fluxes, stocks, biomass, physiological data, and ${ }^{13} \mathrm{C}$-phytodetritus tracer data. Given the required model assumptions and data conversions, the model fit of the tracer data is adequate with the model output being in the same order of magnitude as the tracer data (Figs. 1, 3). The model output is in most cases, however, not within the standard deviation of the tracer data, which can be explained by several factors. The standard deviation (based on 3-5 incubation chambers at each time step) of some of the isotope tracer data may be underestimated because uncertainties in conversion factors are not propagated to the final standard deviation, e.g., for the conversion from bacterial fatty acid biomarkers to bacterial biomass. Moreover, the initial bacterial and faunal biomass may differ between the lander chambers, resulting in differences in ${ }^{13} \mathrm{C}$ incorporation and respiration, whereas the model calculates with one biomass. The two most important conclusions of this study are that bacteria dominate carbon cycling in the PAP sediment (Fig. 4) and labile phytodetritus is a limited carbon source for benthic biota ranging from bacteria to macrobenthos (Figs. 5, 6). We emphasize here that both conclusions are robust. The respiration rate of bacteria is based on bacterial production measurements and literature constraints on bacterial growth efficiency, whereas faunal respiration rates are based on biomass data and established physiological constraints for growth and maintenance respiration. The resulting rates have a low uncertainty (Table 5) and the contribution to total respiration by faunal compartments ranges from $0.01 \%$ to $5.6 \%$ and that of bacteria is $80 \%$ (Table 5). Even if faunal respiration was underestimated, the difference in respiration rates between fauna and bacteria is too large to be explained by erroneous assumptions on the physiological constraints.

The most important shortcoming in the data set is probably that the well-studied megabenthos, especially holothurians, is not included in the ${ }^{13} \mathrm{C}$-phytodetritus study, due to the small size of the sediment cores. This implies that the contribution of labile detritus in the diets of the megabenthic compartments could not be readily constrained (Fig. 6).

Food web structure: carbon flows, production, respiration, and ecosystem efficiency - Regression analysis of biomass and abundance data of different size classes of benthic biota 


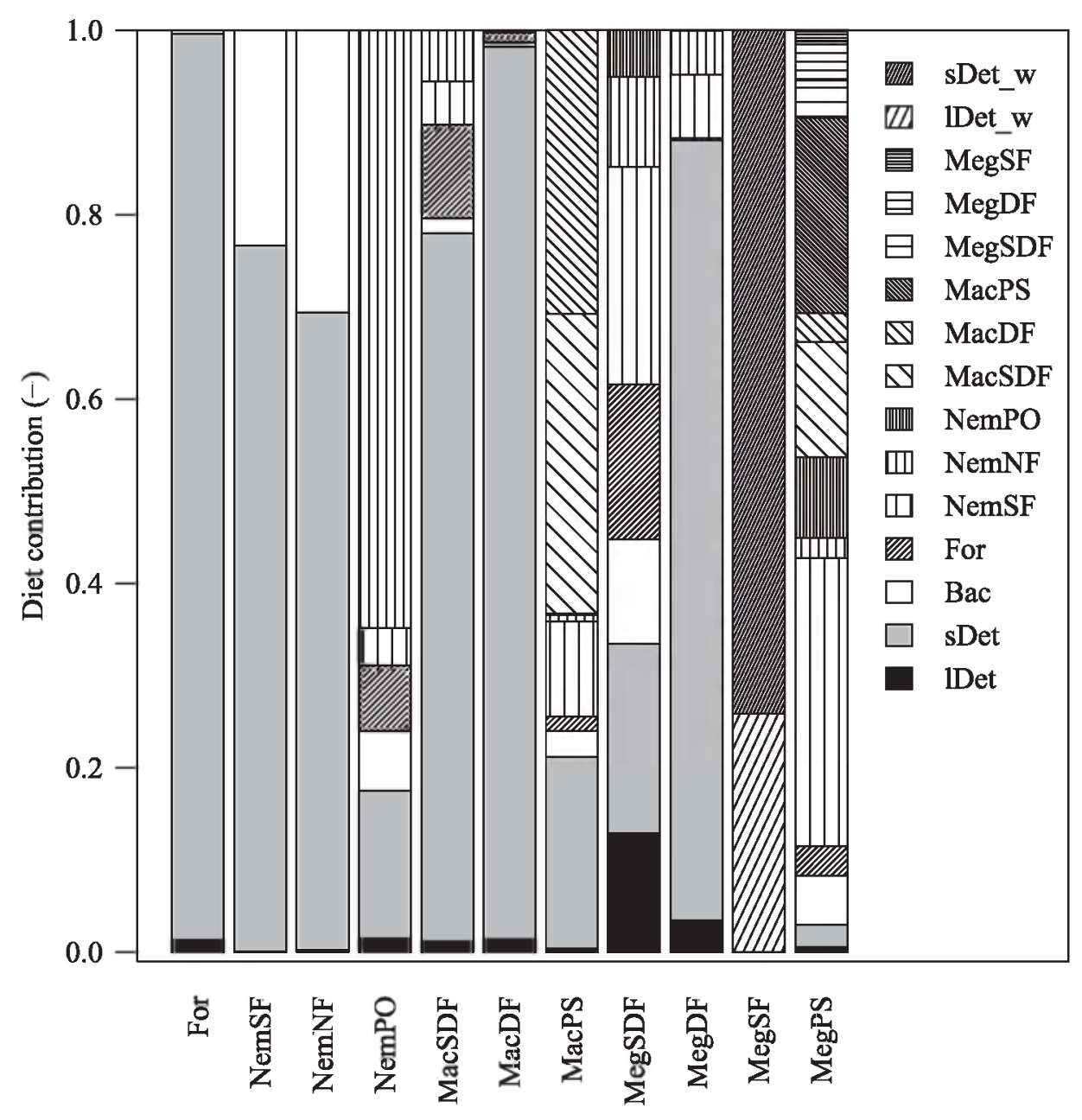

Fig. 5. Diet compositions of the faunal compartments at PAP. See Table 1 for full compartment names.

against water depth suggests that microbes and meiofauna play a disproportionately larger role in energy flows of abyssal plain sediments as compared to shelf and slope sediments (Smith et al. 2008). The dominance of bacteria in carbon cycling in deep sediments is indeed reported in various settings such as the deeper stations of the Goban Spur continental slope (Heip et al. 2001), northern Gulf of Mexico (Rowe et al. 2008), Arctic Ocean (Van Oevelen et al. 2011a), and where the Nazaré Canyon connects to the abyssal plain (Van Oevelen et al. 2011b). A similarly high contribution was found for the PAP, with bacteria being responsible for $80 \%$ of the total respiration and $26 \%$ of the secondary production. The lower contribution to the secondary production results from the lower growth efficiency of bacteria. In addition, this study allowed separating the pathways of detritus with different labilities (Fig. 4). Although bacteria respire $0.36 \mathrm{mmol} \mathrm{C} \mathrm{m} \mathrm{m}^{-2} \mathrm{~d}^{-1}$, the flow from labile detritus to DOC is only $0.02 \mathrm{mmol} \mathrm{C} \mathrm{m} \mathrm{C} \mathrm{d}^{-1}$, indicating limited dependence of the total community respiration on labile detritus (see below for further discussion).

The predominance of small organisms in abyssal sediments has led Smith et al. (2008) to suggest that these ecosystems are inefficient at biomass production compared to bathyal systems. For the PAP, we define ecosystem efficiency as a ratio of fluxes : total secondary production by meio-, macro-, and megabenthos divided by total detritus input. This measure gives an ecosystem efficiency of $15 \%$, which is higher than the food web efficiency of a bacterial-based $(2 \%)$ and comparable to the phytoplankton-based $(22 \%)$ pelagic food web in the Baltic Sea (Berglund et al. 2007). However, if we exclude secondary production that is consumed within the benthic food web itself and consider for the ecosystem efficiency measure only the secondary production that is available for consumption by higher trophic levels (i.e., the export production by macro- and megabenthos, Table 5), then this efficiency drops to $0.4 \%$, suggesting indeed a lower efficiency food web in abyssal plain sediments. Note, however, for comparison that the food web efficiency for the production of higher trophic level fish species such as Atlantic cod (Gadus morhua) in the Barents Sea was even lower and ranged from $1 \times 10^{-3 \%}$ to $1 \times 10^{-4 \%}$ (De Laender et al. 2010).

Deposition of total and labile detritus - The model results indicate a total detritus deposition of $0.56[0.53-0.57] \mathrm{mmol}$ 


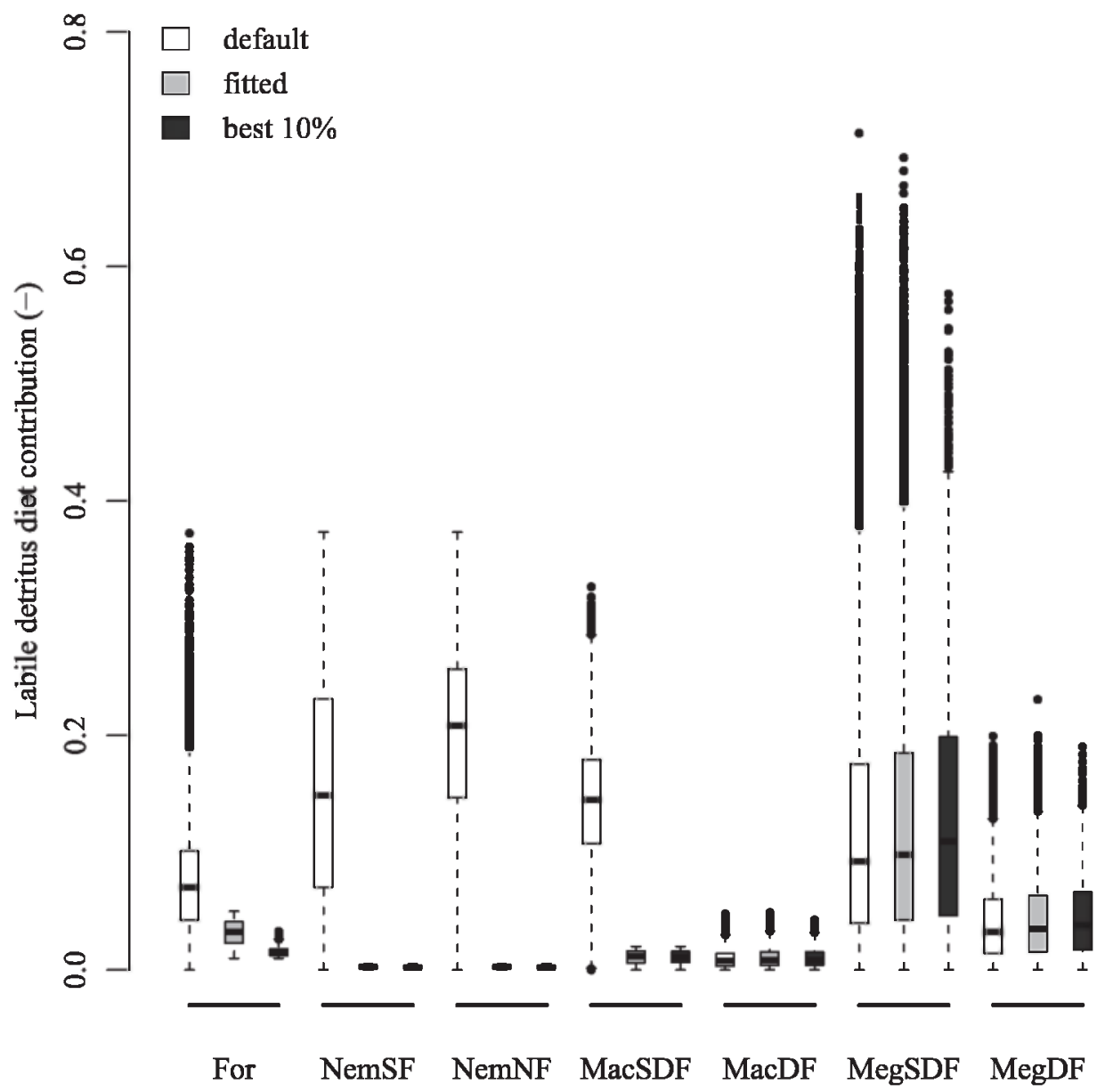

Fig. 6. Boxplots of labile detritus contributions in the solutions sets of the default LIM, the fitted LIM, and the best $10 \%$ of the fitted LIM in the faunal compartments. See Table 1 for full compartment names.

$\mathrm{C} \mathrm{m}^{-2} \mathrm{~d}^{-1}$ that is dominated by semi-labile (43\%) and refractory $(53 \%)$ detritus. These results are partly influenced by the data from ${ }^{13} \mathrm{C}$ isotope tracer study (see discussion below), but may also be related to processes in the upper water column. The organic export flux at the PAP from the upper water column measured at $3000 \mathrm{~m}$ shows considerable temporal variation, with a $\max : \min$ ratio of the annual flux of 6.45 measured over $14 \mathrm{yr}$ (Lampitt et al. 2010 h). Monthly averages in winter are lower and less variable $(<0.25 \mathrm{mmol}$ C $\mathrm{m}^{-2} \mathrm{~d}^{-1}$ ) as compared to July-September values (1.25 mmol $\mathrm{C} \mathrm{m}^{-2} \mathrm{~d}^{-1}$ ) when standard deviations exceed $100 \%$. Also, the composition of the export flux varies strongly as shown by both changes in $\mathrm{C}: \mathrm{N}$ ratio and the ratio of $\mathrm{POC}$ to particulate inorganic carbon. The variation in quantity and quality was partially explained by the timing of shoaling of the mixing depth and the algal species composition in the upper water column (Lampitt et al. $2010 \mathrm{~b})$. Total detritus deposition inferred from deep $(4700 \mathrm{~m})$ sediment traps ranged from 0.187 to $0.258 \mathrm{mmol} \mathrm{C} \mathrm{m}^{-2} \mathrm{~d}^{-1}$ in the years 1997-1999, which was insufficient to meet the sediment oxygen demand of $0.45 \mathrm{mmol} \mathrm{C} \mathrm{m}^{-2} \mathrm{~d}^{-1}$ as measured by the chamber incubations (Lampitt et al. 2001). A similar discrepancy between supply and demand was observed at the long-term observatory Sta. M in the Pacific Ocean (Smith and Kaufmann 1999) and may be partially explained by lateral, rather than vertical, input of organic detritus (Smith et al. 2001). Because of the distance from the continental shelf, advective inputs are not considered quantitatively important at the PAP (Billett and Rice 2001), but the resuspension factor (ratio of POC flux close to the seafloor against POC flux distant from the seafloor) is frequently $>1$, especially at lower absolute levels of detritus input (Lampitt et al. 2001). These resuspension events may partly explain the inferred importance of semilabile and refractory detritus at the PAP (Fig. 4). Furthermore, Lampitt et al. (2010b) finds that unusual events in the water column occur in the springtime, whereas those at $3000-$ $m$ water depth occur late summer. This indicates that material retention in the mesopelagic zone, e.g., through variation in mineralization and sinking rate, are important controlling factors on the quantity and quality of the export flux reaching the seafloor (Lampitt et al. 2010b).

The PAP is known for its seasonal and episodic detritus inputs (Lampitt et al. 2010b), which may result in visually detectable phytodetritus aggregates on the seafloor (Smith et al. 2009). To accommodate this in the model input, a large range for labile detritus deposition was included in the model (Table 2). This range corresponds to conditions of low phytodetritus input and bare sediment to high input when a thin greenish layer was visible on the seafloor 
(Witbaard et al. 2000). The model analysis subsequently inferred a labile detritus input of 0.021 [ 0.0140 .023$] \mathrm{mmol}$ $\mathrm{C} \mathrm{m}^{-2} \mathrm{~d}^{-1}$ (3.8\% of total input), which is low compared to other studies. Stephens et al. (1997) estimated the labile detritus contribution by conversion from $\mathrm{Chl} a$ flux data and could explain $25-100 \%$ of the total detritus input. Soetaert et al. (1996) found that a contribution of $70 \%$ of labile detritus input was needed to reproduce observed SCOC dynamics at Sta. M with a diagenetic model.

The low contribution of labile detritus in our results is probably due to two reasons. Firstly, the detrital carbon flux associated with Chl $a$ under conditions of high phytodetritus input (i.e., green layer visible) of $0.023 \mathrm{mmol}$ $\mathrm{C} \mathrm{m}^{-2} \mathrm{~d}^{-1}$ is low as compared to the SCOC of $0.45 \mathrm{mmol} \mathrm{C}$ $\mathrm{m}^{-2} \mathrm{~d}^{-1}$ (Table 2). Hence, our operational definition of labile detritus essentially determines this low contribution. Secondly, the low labile detritus deposition is also constrained by the low uptake of ${ }^{13} \mathrm{C}$ in the isotope tracer study by different faunal compartments (Figs. 1, 5). Although Witte et al. (2003) measured the response of most benthic compartments, the megabenthos was not included in the experimental design because of the comparatively small size of the incubation chambers. Megabenthic species, most notably holothurians, are considered important grazers of labile phytodetritus at the PAP (Bett et al. 2001; Wigham et al. 2003) and the model may have underestimated their uptake of labile detritus, thus explaining the low labile detritus contribution.

The model was used to investigate both explanations. An inverse model was set up in which the rates that were well constrained by the ${ }^{13} \mathrm{C}$ tracer study were fixed, namely consumption of labile detritus by Foraminifera, nematode, and macrobenthic compartments, as well as the contribution of labile detritus in the DOC uptake by bacteria. The imposed upper limit on labile detritus deposition, a resultant of our choice to use Chl $a$ to define labile detritus, was removed from the model. We then ran the model using "range estimation," a procedure that finds min-max values for flows in a food web (Soetaert and Van Oevelen 2009), to find the maximum allowable deposition rate of labile detritus that was still consistent with the model. The maximum consistent deposition rate of labile detritus was $0.044 \mathrm{mmol} \mathrm{C} \mathrm{m}^{-2} \mathrm{~d}^{-1}$, of which $\sim 80 \%$ dissolves into DOC (and may subsequently be taken up by bacteria or efflux to the water column), $\sim 10 \%$ is consumed by megabenthos, and the remainder is processed by the rest of the food web. This model exercise gives two clear answers. Maximum labile detritus can only be $\sim 2 \times$ higher than the current fitted LIM solution, while respecting the data on total carbon and ${ }^{13} \mathrm{C}$ processing by the food web. The biomass of megabenthos (predominantly holothurians) as implemented in the model corresponds to periods of high megabenthic biomass at the PAP between 1996 and 1998 (Table 1 and Smith et al. 2009), but this biomass can remove $\sim 10 \%$ of the maximum allowable labile detritus input (corresponding to high diet contributions of $23 \%$ and $86 \%$ for MegDF and MegSDF, respectively). We conclude that given current biomass estimates of megabenthos, their potential to remove a substantial fraction of the labile detritus input is low. It is, however, suggested that trawl inefficiencies may seriously under-sample holothurian densities, especially small individuals. Estimates from comparisons with video observations suggest that the small and light holothurian $A$. rosea may be under-sampled up to a factor of 17 by trawling (Billett et al. 2010). A. rosea is not an important biomass component, but is considered to be an important grazer of labile phytodetritus at the PAP (Wigham et al. 2003). Hence, better biomass estimates of holothurians and quantitative data on their uptake rates of ${ }^{13} \mathrm{C}$-phytodetritus are needed to further constrain their contribution to labile phytodetritus processing.

(Un)importance of labile detritus for the benthic community-There is an evident connection between detritus input to deep sediments and the residing benthic biota. Detritus is, however, often treated as a single compartment, whereas in reality detritus is a heterogeneous mixture of compounds of different composition and reactivity. This heterogeneity applies to detritus in the sediment (Middelburg and Meysman 2007), resuspended detritus (Graf 1992), and also to phytodetritus prior to settling on the seafloor (Harvey et al. 1995). This heterogeneity is well established, and different biochemical compounds such as pigments (Sun et al. 1991), lipids (Sun et al. 2002), and amino acids (Dauwe et al. 1999) are used to describe the degradation state of detritus. It remains, however, hard to distinguish quantitatively the processing of different lability classes of detritus. In this paper, an attempt is made to separate detritus into several lability classes and following its fate through an abyssal plain food web. Although this division in detritus classes is by no means unambiguous, our modeling results decidedly show that the labile detritus fulfills only a limited fraction of the carbon demands of bacteria, Foraminifera, nematodes, and macrobenthos (Figs. 4, 6). Also, the low contribution of the labile detritus in the food web is a robust result. The solution of the default LIM, i.e., without the isotope tracer constraints, encompassed a large range of labile detritus contributions in the faunal diets (Fig. 6), but the best fit grossly overestimated faunal ${ }^{13} \mathrm{C}$ tracer incorporations (Fig. 1). Also, the upper boundaries of the uncertainty bands (gray areas in Fig. 1) overestimate the ${ }^{13} \mathrm{C}$ tracer incorporation by the faunal compartments. These upper boundaries, however, correspond to very low contributions of labile detritus in the diets of the benthic fauna (Fig. 6). This study is unique for the abyssal plain, but a comparable study was conducted for the continental slope of the Faroe Shetland Channel (1080 m) (Gontikaki et al. 2011). Similar results were obtained, since $\leq 5 \%$ of the carbon demands was fulfilled by labile detritus for two size classes of nematodes, various feeding types of polychaetes, and three other macrobenthic compartments.

The results with respect to the low uptake of labile detritus are predominantly steered by the low uptake of ${ }^{13} \mathrm{C}$ in the isotope tracer studies (Witte et al. 2003; Gontikaki et al. 2011). It is therefore important that the isotope tracing methodology readily mimics the uptake of a natural phytodetritus pulse by the benthic community. Isotope tracer studies mostly use a single diatom species that is cultured axenically (to allow estimating uptake by bacteria) and freeze-dried (to facilitate settling in the experimental 
chambers). Whether the fate of such an algal tracer mimics the fate of natural phytodetritus has not been tested experimentally. Several species of Foraminifera (Moodley et al. 2002) and some polychaetes (Levin et al. 1997) have, however, been shown to take up a substantial amount of the algal tracer. Finally, the carbon loads used in these studies are comparably high (approximately the annual detritus deposition), ensuring a high availability of the ${ }^{13} \mathrm{C}$-phytodetritus. Overall, this suggests that the isotope tracer studies may reasonably mimic a natural phytodetritus deposition, but additional experiments are required to verify the isotope tracer methodology.

Several lines of evidence support our findings of the low importance of labile detritus for deep benthic food webs. At the community scale, Smith et al. (1998) measured only a small $(<1 \%)$ contribution to the SCOC that could be attributed to the mineralization of recently deposited detrital aggregates at Sta. M. Similarly, Witbaard et al. (2000) did not find significant differences between the SCOC during different regimes of $\mathrm{Chl} a$ input at PAP. Measurements of SCOC at the PAP measured at different months and years center around $0.44-0.45 \mathrm{mmol} \mathrm{C} \mathrm{m}^{-2} \mathrm{~d}^{-1}$ (Witbaard et al. 2000; Witte et al. 2003; Ståhl et al. 2004), suggesting that benthic metabolism is dominated by less labile detritus pool that is not susceptible to strong dynamics.

Since sediment respiration is dominated by bacteria (Table 5), any faunal response to the phytodetritus pulse may be masked in the SCOC dynamics. However, there is also evidence from direct observations of the megafauna. Bett et al. (2001) estimated from the abundance and activity of $A$. rosea as seen in time-lapse photography (as opposed to the biomass data based on trawls in Table 1) that this holothurian was most likely responsible for removal of the majority of the incoming phytodetritus flux. If true, this implies that other species in the food web are forced to live on lower quality detritus. Indeed, Neto et al. (2006) reported that other holothurians may switch from labile to less labile detritus or not feed on labile detritus at all. Ramirez-Llodra et al. (2005) suggested that holothurians, most notably $A$. rosea, reduced the availability of trophic resources, leading to a reduction in the reproductive effort of the holothurian Oneirophanta mutabilis. Moreover, Aberle and Witte (2003) reported large taxa-specific differences in the uptake of ${ }^{13} \mathrm{C}$-phytodetritus at the PAP. Drazen et al. (2008) conducted a study on the fatty acid composition of abyssal plain fauna in the Northeast Pacific and concluded that phytodetritus was only a small component of their diet. Iken et al. (2005) studied $\delta^{15 \mathrm{~N}}$ signatures of benthic fauna in the Canada Basin and inferred that most deposit feeders relied largely on refractory detritus, because of the difference in $\delta^{15} \mathrm{~N}$ signature between deposit feeders and fresh phytodetritus. There is thus additional evidence that not all benthic fauna have strong linkages to labile phytodetritus and that there is large variability in dependence on labile phytodetritus.

A predominant dependence on semi-labile carbon sources by benthic fauna has important ramifications for the functioning of deep benthic food webs. Semi-labile detritus has, by definition, a lower specific degradation rate and a comparatively larger stock size as compared to labile detritus (Table 1). This implies that intra- and interannual variations in detritus input from the water column, which can be significant even for abyssal plain sediments (Smith et al. 2008; Smith et a1. 2009; Lampitt et al. 2010b), do not result in a large variation in food availability for the benthic community. For the PAP site, for example, the semi-labile detritus pool was estimated at $1940 \mathrm{mmol} \mathrm{C} \mathrm{m}^{-2}$, monthly peak fluxes after the spring bloom at the PAP are usually between 10 and $20 \mathrm{mg}$ POC $\mathrm{m}^{-2} \mathrm{~d}^{-1}$, but can reach a maximum of 40 to $60 \mathrm{mg} \mathrm{POC} \mathrm{m} \mathrm{m}^{-2} \mathrm{~d}^{-1}$ (Smith et al. 2009). If we assume that this flux is solely semi-labile detritus, then we find maximum increases in the semi-labile detritus pool of $1 \%$ to $8 \%$. These comparatively small increases in food availability are unlikely to result in major and rapid increases in the biomass of most benthic food web compartments.

In conclusion, our modeling analysis at the PAP indicates that bacteria are the dominant compartment in carbon processing. Surprisingly, diet compositions of Foraminifera and meio- and macrobenthos showed unambiguously that labile detritus contributed only a few percent to their total carbon demands. The strong dependence on semi-labile detritus implies that these compartments depend on a rather stable (at least on annual scales) food source. Better biomass estimates of holothurians and quantitative data on their uptake rates of ${ }^{13} \mathrm{C}$-phytodetritus are needed to further constrain their contribution to labile phytodetritus processing, but with current biomass estimates of megabenthos (i.e., inferred from trawl data) it appears that their potential to remove a substantial fraction of the labile detritus input is low. Climate change is expected to induce changes in the quantity and quality of the export fluxes from the upper water column to the sediment (Smith et al. 2008). The total export flux is expected to decrease because higher sea surface temperature will shoal the mixed layer and enhance stratification, thereby increasing nutrient limitation and reducing the amount of detritus export to the benthos. The quality of the export flux will possibly change with an increase in the $\mathrm{C}: \mathrm{N}$ ratio of the export flux, due to nutrient limitation and $\mathrm{CO}_{2}$ absorption, and through possible changes in the phytoplankton community structure. Results from this study indicate that an important part of the benthic biomass depends on a more stable carbon for their carbon demands, which implies that changes on the benthic community may lag behind the changes seen in the water column, rendering long-term monitoring programs indispensable to detect these changes. Predictions at the species level are much more difficult to make, partly because there may be a high variability in dependence on labile phytodetritus among species.

\section{Acknowledgments}

Ursula Witte is thanked for making the original data from the isotope enrichment experiment at the PAP available to us. We also thank two anonymous reviewers and Bo Thamdrup for the constructive comments that helped to improve and focus the manuscript. This research was supported by the Hotspot Ecosystem Research along the Margins of the European Seas (HERMES) project, contract GOCE-CT-2005-511234, funded by the European Commission's Sixth Framework Programme under the priority "Sustainable Development, Global Change and Ecosystems" and the Hotspot Ecosystem Research and Man's Impact On European 
Seas (HERMIONE) project, grant agreement 226354, funded by the European Community's Seventh Framework Programme (FP7) 2007-2013). This is publication 5193 from the Netherlands Institute of Ecology (NIOO-KNAW), Yerseke.

\section{References}

Aberle, N., AND U. WitTe. 2003. Deep-sea macrofauna exposed to a simulated sedimentation event in the abyssal NE Atlantic: In situ pulse-chase experiments using C-13-labelled phytodetritus. Mar. Ecol. Prog. Ser. 251: 37-47, doi:10.3354/meps251037

Amaro, T., S. Bianchelli, D. S. M. Billett, M. R. Cunha, A. Pusceddu, and R. Danovaro. 2010. The trophic biology of the holothurian Molpadia musculus: Implications for organic matter cycling and ecosystem functioning in a deep submarine canyon. Biogeosciences 7: 2419-2432, doi:10.5194/bg-7-2419-2010

Benner, R., M. A. Moran, and R. E. Hodson. 1986. Biogeochemical cycling of lignocellulosic carbon in marine and freshwater ecosystems: Relative contributions of procaryotes and eucaryotes. Limnol. Oceanogr. 31: 89-100, doi:10.4319/ 10.1986.31.1.0089

Berglund, J., U. Muren, U. Bamstedt, and A. Andersson. 2007. Efficiency of a phytoplankton-based and a bacteria-based food web in a pelagic marine system. Limnol. Oceanogr. 52: 121-131, doi:10.4319/10.2007.52.1.0121

Bett, B. J., M. G. Malzone, B. E. Narayanaswamy, and B. D. Wigham. 2001. Temporal variability in phytodetritus and megabenthic activity at the seabed in the deep Northeast Atlantic. Prog. Oceanogr. 50: 349-368, doi:10.1016/S00796611(01)00066-0

Billett, D. S. M., B. J. Bett, W. D. K. Reid, B. Boorman, And I. G. Priede. 2010. Long-term change in the abyssal NE Atlantic: The 'Amperima Event' revisited. Deep-Sea Res. II 57: 1406-1417, doi:10.1016/j.dsr2.2009.02.001

A. L. Rice, M. H. Thurston, J. Galéron, M. Sibuet, AND G. A. WolfF. 2001. Long-term change in the megabenthos of the Porcupine Abyssal Plain (NE Atlantic). Prog. Oceanogr. 50: 325-348, doi:10.1016/S0079-6611(01)00060-X

R. S. Lampitt, A. L. Rice, and R. F. C. Mantoura. 1983. Seasonal sedimentation of phytoplankton to the deep-sea benthos. Nature 302: 520-522, doi:10.1038/302520a0

AND A. L. Rice. 2001. The BENGAL programme: Introduction and overview. Prog. Oceanogr. 50: 13-25, doi:10.1016/S0079-6611(01)00046-5

Blair, N. E., L. A. Levin, D. J. Demaster, and G. Plaia. 1996. The short-term fate of fresh algal carbon in continental slope sediments. Limnol. Oceanogr. 41: 1208-1219, doi:10.4319/ 10.1996.41.6.1208

Bock, M. J., AND D. C. Mlller. 1999. Particle selectivity, gut volume, and the response to a step change in diet for depositfeeding polychaetes. Limnol. Oceanogr. 44: 1132-1138, doi:10.4319/10.1999.44.4.1132

Burdige, D. J. 2006. Geochemistry of marine sediments. Princeton Univ. Press.

, W. M. Berelson, K. H. Coale, J. Mcmanus, and K. S. Johnson. 1999. Fluxes of dissolved organic carbon from California continental margin sediments. Geochim. Cosmochim. Acta 63: 1507-1515, doi:10.1016/S0016-7037(99)00066-6

Danovaro, R., A. Dell'anno, C. Corinaldesi, M. Magagnini, R. Noble, C. Tamburini, and M. Weinbauer. 2008. Major viral impact on the functioning of benthic deep-sea ecosystems. Nature 454: 1084-1088, doi:10.1038/nature07268 , AND M. FABIANo. 2001. Bioavailability of organic matter in the sediments of the Porcupine Abyssal Plain, northeastern Atlantic. Mar. Ecol. Prog. Ser. 220: 25-32, doi: $10.3354 / \mathrm{meps} 220025$
Daume, B., J. J. Middelburg, P. M. J. Herman, and C. H. R HeIP. 1999. Linking diagenetic alteration of amino acids and bulk organic matter reactivity. Limnol. Oceanogr. 44: 1809-1814, doi:10.4319/lo.1999.44.7.1809

De Laender, F., D. Van Oevelen, K. Soetaert, and J. J. Middelburg. 2010. Carbon transfer in herbivore- and microbial loop-dominated pelagic food webs in the southern Barents Sea during spring and summer. Mar. Ecol. Prog. Ser. 398: 93-107, doi:10.3354/meps08335

Del Giorgio, P. A., And J. J. Cole. 1998. Bacterial growth efficiency in natural aquatic systems. Annu. Rev. Ecol. Syst. 29: 503-541, doi:10.1146/annurev.ecolsys.29.1.503

Deming, J. W., And J. A. Baross. 1993. The early diagenesis of organic matter: Bacterial activity, p. 119-144. In M. H. Engel and S. A. Macko [eds.], Organic geochemistry. Plenum Press.

Demopoulos, A. W. J., C. R. Smith, D. J. Demaster, and W. L. FORNES. 2003. Evaluation of excess Th-234 activity in sediments as an indicator of food quality for deep-sea deposit feeders. J. Mar. Res. 61: 267-284, doi:10.1357/002224003322005096

Drazen, J. C., C. F. Phleger, M. A. Guest, And P. D. Nichols. 2008. Lipid, sterols and fatty acids of abyssal polychaetes, crustaceans, and a cnidarian from the northeast Pacific Ocean: Food web implications. Mar. Ecol. Prog. Ser. 372: 157-167, doi: $10.3354 /$ meps07707

Eardly, D. F., M. W. Carton, J. M. Gallagher, and J. W. Patching. 2001. Bacterial abundance and activity in deep-sea sediments from the eastern North Atlantic. Prog. Oceanogr. 50: 245-259, doi:10.1016/S0079-6611(01)00056-8

EldRidge, P. M., AND G. A. JACKson. 1993. Benthic trophic dynamics in California coastal basin and continental slope communities inferred using inverse analysis. Mar. Ecol. Prog. Ser. 99: 115-135, doi:10.3354/meps099115

Epping, E., C. Van Der Zee, K. Soetaert, and W. Helder. 2002. On the oxidation and burial of organic carbon in sediments of the Iberian margin and Nazare Canyon (NE Atlantic). Prog. Oceanogr. 52: 399-431, doi:10.1016/S0079-6611(02)00017-4

Fabiano, M., A. Pusceddu, A. Dell'anno, M. Armeni, S. Vanucci, R. S. Lampitt, G. A. Wolff, and R. Danovaro. 2001. Fluxes of phytopigments and labile organic matter to the deep ocean in the NE Atlantic Ocean. Prog. Oceanogr. 50: 89-104, doi:10.1016/S0079-6611(01)00049-0

Fauchald, K., AND P. A. Jumars. 1979. The diet of worms: A study of polychaete feeding guilds. Oceanogr. Mar. Biol. Annu. Rev. 39: 193-284.

Flach, E., M. Lavaleye, H. De Stigter, and L. Thomsen. 1998. Feeding types of the benthic community and particle transport across the slope of the NW European Continental Margin (Goban Spur). Prog. Oceanogr. 42: 209-231, doi:10.1016/S0079-6611(98)00035-4

, A. Muthumbi, ANd C. Heip. 2002. Meiofauna and macrofauna community structure in relation to sediment composition at the Iberian margin compared to the Goban Spur (NE Atlantic). Prog. Oceanogr. 52: 433-457, doi:10. 1016/S0079-6611(02)00018-6

Galéron, J., M. Sibuet, A. Vanreusel, K. Mackenzie, A. J. Gooday, A. Dinet, And G. A. WolfF. 2001. Temporal patterns among meiofauna and macrofauna taxa related to changes in sediment geochemistry at an abyssal NE Atlantic site. Prog. Oceanogr. 50: 303-324, doi:10.1016/S0079-6611(01)00059-3

Ginger, M. L., D. S. M. Billett, K. L. Mackenzie, K. Kiriakoulakis, R. R. Neto, D. K. Boardman, V. Santos, I. M. Horsfall, and G. A. WolfF. 2001. Organic matter assimilation and selective feeding by holothurians in the deep sea: Some observations and comments. Prog. Oceanogr. 50: 407-421, doi:10.1016/S0079-6611(01)00063-5 
GLud, R. N. 2008. Oxygen dynamics of marine sediments. Mar. Biol. Res. 4: 243-289, doi:10.1080/17451000801888726

Gontikaki, E., D. Van Oevelen, K. Soetaert, and U. Witte. 2011. Food web flows through a sub-arctic deep-sea benthic community. Prog. Oceanogr. 91: 245-259, doi:10.1016/j.pocean. 2010.12 .014

GraF, G. 1992. Benthic-pelagic coupling - a benthic view. Oceanogr. Mar. Biol. 30: 149-190.

Hall, P. O. J., J. Brunnegard, G. Hulthe, W. R. Martin, H. Stahl, And A. Tengberg. 2007. Dissolved organic matter in abyssal sediments: Core recovery artifacts. Limnol. Oceanogr. 52: 19-31, doi:10.4319/10.2007.52.1.0019

Harvey, H. R., J. H. Tuttle, and J. T. Bell. 1995. Kinetics of phytoplankton decay during simulated sedimentationchanges in biochemical-composition and microbial activity under oxic and anoxic conditions. Geochim. Cosmochim. Acta 59: 3367-3377, doi:10.1016/0016-7037(95)00217-N

Heip, C. H. R., G. Duineveld, E. Flach, G. Graf, W. Helder, P. M. J. Herman, M. Lavaleye, J. J. Middelburg, O. Pfannkuche, K. Soetaert, T. Soltwedel, H. De Stigter, L. Thomsen, J. Vanaverbeke, and P. De Wilde. 2001. The role of the benthic biota in sedimentary metabolism and sediment-water exchange processes in the Goban Spur area (NE Atlantic). Deep-Sea Res. II 48: 3223-3243, doi:10.1016/ S0967-0645(01)00038-8

Hendriks, A. J. 1999. Allometric scaling of rate, age and density parameters in ecological models. Oikos 86: 293-310, doi: $10.2307 / 3546447$

Henrichs, S. M., and A. P. Doyle. 1986. Decomposition of ${ }^{14} \mathrm{C}$-labelled organic substances in marine sediments. Limnol. Oceanogr. 31: 765-778, doi:10.4319/10.1986.31.4.0765

Iken, K., B. A. Bluhm, And R. Gradinger. 2005. Food web structure in the high Arctic Canada Basin: Evidence from delta C-13 and delta N-15 analysis. Polar Biol. 28: 238-249, doi:10.1007/s00300-004-0669-2

, T. Brey, U. WAND, J. Voigt, and P. Junghans. 2001. Food web structure of the benthic community at the Porcupine Abyssal Plain (NE Atlantic): A stable isotope analysis. Prog. Oceanogr. 50: 383-405, doi:10.1016/S00796611(01)00062-3

KhripounofF, A., AND M. Sibuet. 1980. The nutrition of abyssal echinoderms. 1. Feeding holothuriods. Mar. Biol. 60: 17-26, doi: $10.1007 / \mathrm{BF} 00395602$

Lahajnar, N., T. Rixen, B. Gaye-HaAke, P. Schäfer, and V. Itтеккот. 2005. Dissolved organic carbon (DOC) fluxes of deep-sea sediments from the Arabian Sea and NE Atlantic. Deep-Sea Res. II 52: 1947-1964, doi:10.1016/j.dsr2.2005.05.006

Lampitt, R. S., B. J. Bett, K. Kiriakoulakis, E. E. Popova, O. Ragueneau, A. Vangriesheim, AND G. A. WolfF. 2001. Material supply to the abyssal seafloor in the Northeast Atlantic. Prog. Oceanogr. 50: 27-63, doi:10.1016/S0079-6611 (01)00047-7

—, D. S. M. Billett, And A. P. Martin. 2010a. The sustained observatory over the Porcupine Abyssal Plain (PAP): Insights from time series observations and process studies. Preface. Deep-Sea Res. II 57: 1267-1271, doi:10.1016/ j.dsr2.2010.01.003

- I. Salter, B. A. De Cuevas, S. Hartman, K. E. Larkin, And C. A. Pebody. 2010b. Long-term variability of downward particle flux in the deep northeast Atlantic: Causes and trends. Deep-Sea Res. II 57: 1346-1361, doi:10.1016/j.dsr2. 2010.01.011

Levin, L., N. Blair, D. Demaster, G. Plaia, W. Fornes, C. Martin, And C. Thomas. 1997. Rapid subduction of organic matter by maldanid polychaetes on the North Carolina slope. J. Mar. Res. 55: 595-611, doi:10.1357/0022240973224337
MAY, R. M. 1973. Stability and complexity in model ecosystems. Princeton Univ. Press.

Mayer, L. M., L. L. Schick, T. Sawyer, C. J. Plante, P. A. Jumars, AND R. L. SelF. 1995. Bioavailable amino-acids in sediments a biomimetic, kinetics-based approach. Limnol. Oceanogr. 40: 511-520, doi:10.4319/lo. 1995.40.3.0511

R. F. L. Self, P. A. Jumars, R. H. Findlay, Z. Chen, AND S. Sampson. 1997. Digestive environments of benthic macroinvertebrate guts: Enzymes, surfactants and dissolved organic matter. J. Mar. Res. 55: 785-812, doi:10. $1357 / 0022240973224247$

Middelboe, M., And R. N. Glud. 2006. Viral activity along a trophic gradient in continental margin sediments off central Chile. Mar. Biol. Res. 2: 41-51, doi:10.1080/ 17451000600620650

Middelburg, J. J., And F. J. R. Meysman. 2007. Ocean scienceburial at sea. Science 316: 1294-1295, doi:10.1126/science.1144001

, H. T. S. Boschker, G. C. A. Duineveld, R. Pel, P. M. J. Herman, and C. H. R. Heip. 2002. Bacteria and Foraminifera: Key players in a short-term deep-sea benthic response to phytodetritus. Mar. Ecol. Prog. Ser. 236: 23-29, doi: $10.3354 /$ meps 236023

Moodley, L., J. J. Middelburg, K. Soetaert, H. T. S. BoschKer, P. M. J. Herman, and C. H. R. Heip. 2005. Similar rapid response to phytodetritus deposition in shallow and deepsea sediments. J. Mar. Res. 63: 457-469, doi:10.1357/ 0022240053693662

Neto, R. R., G. A. Wolff, D. S. M. Billett, K. L. Mackenzie, AND A. Thompson. 2006. The influence of changing food supply on the lipid biochemistry of deep-sea holothurians. Deep-Sea Res. I 53: 516-527, doi:10.1016/j.dsr.2005.12.001

Ramirez-Llodra, E., W. D. K. Reid, AND D. S. M. Billett. 2005. Long-term changes in reproductive patterns of the holothurian Oneirophanta mutabilis from the Porcupine Abyssal Plain. Mar. Biol. 146: 683-693, doi:10.1007/s00227-004$1470-z$

R Development Core Team. 2011. R: A language and environment for statistical computing [Internet]. Vienna, Austria: R Foundation for Statistical Computing [accessed 2012 January 10]. Available from http://www.R-project.org

Rowe, G. T. 1983. Biomass and production of the deep-sea macrobenthos, p. 97-121. In G. T. Rowe [ed.], Deep sea biology. The sea: Ideas and observations on progress in the study of the seas. Harvard Univ. Press.

, C. L. Wei, C. Nunnally, R. Haedrich, P. Montagna, J. G. Baguley, J. M. Bernhard, M. Wicksten, A. Ammons, E. E. Briones, Y. Soliman, And J. W. Deming. 2008. Comparative biomass structure and estimated carbon flow in food webs in the deep Gulf of Mexico. Deep-Sea Res. II 55: 2699-2711, doi:10.1016/j.dsr2.2008.07.020

Ruhl, H. A. 2007. Abundance and size distribution dynamics of abyssal epibenthic megafauna in the northeast Pacific. Ecology 88: 1250-1262, doi:10.1890/06-0890

—, J. A. Ellena, And K. L. Smith. 2008. Connections between climate, food limitation, and carbon cycling in abyssal sediment communities. Proc. Natl. Acad. Sci. USA 105: 17006-17011, doi:10.1073/pnas.0803898105

Sebastian, S., M. Raes, I. De Mesel, and A. Vanreusel. 2007. Comparison of the nematode fauna from the Weddell Sea abyssal plain with two North Atlantic abyssal sites. Deep-Sea Res. II 54: 1727-1736, doi:10.1016/j.dsr2.2007.07.004

Smith, C. R., F. C. De Leo, A. F. Bernardino, A. K. Sweetman, AND P. M. Arbizu. 2008. Abyssal food limitation, ecosystem structure and climate change. Trends Ecol. Evol. 23: 518-528, doi:10.1016/j.tree.2008.05.002 
Smith, K. L., R. J. Baldwin, R. C. Glatts, R. S. Kaufmann, and E. C. Fisher. 1998. Detrital aggregates on the sea floor: Chemical composition and aerobic decomposition rates at a time-series station in the abyssal NE Pacific. Deep-Sea Res. II 45: 843-880, doi:10.1016/S0967-0645(98)00005-8

, AND R. S. KAUFMANN. 1999. Long-term discrepancy between food supply and demand in the deep eastern North Pacific. Science 284: 1174-1177, doi:10.1126/science.284.5417.1174 , R. J. Baldwin, ANd A. F. Carlucci. 2001. Pelagicbenthic coupling in the abyssal eastern North Pacific: An 8year time-series study of food supply and demand. Limnol. Oceanogr. 46: 543-556, doi:10.4319/lo.2001.46.3.0543

, H. A. Ruhl, B. J. Bett, D. S. M. Billett, R. S. LAmpitt, and R. S. Kaufmann. 2009. Climate, carbon cycling, and deep-ocean ecosystems. Proc. Natl. Acad. Sci. USA 106: 19211-19218, doi:10.1073/pnas.0908322106

Soetaert, K., P. M. J. Herman, and J. J. Middelburg. 1996. Dynamic response of deep-sea sediments to seasonal variations: A model. Limnol. Oceanogr. 41: 1651-1668, doi:10.4319/ 10.1996.41.8.1651

, ANd T. PETzoldt. 2010. Inverse modelling, sensitivity and Monte Carlo analysis in $\mathrm{R}$ using package FME. J. Stat. Softw. 33: 1-28.

, AND R. W. SETZER. 2010. deSolve: General solver for initial value problems of ordinary differential equations (ODE), partial differential equations (PDE), differential algebraic equations (DAE), and delay differential equations (DDE). R package version 1.7, http://CRAN.R-project.org/ package $=$ deSolve

- And D. Van Oevelen. 2009. Modeling food web interactions in benthic deep-sea ecosystems: A practical guide. Oceanography 22: 130-145, doi:10.5670/oceanog.2009.13

Ståhl, H., A. Tengberg, J. Brunnegård, and P. O. J. Hall. 2004. Recycling and burial of organic carbon in sediments of the Porcupine Abyssal Plain, NE Atlantic. Deep-Sea Res. I 51: 777-791, doi:10.1016/j.dsr.2004.02.007

Stephens, M. P., D. C. Kadko, C. R. Smith, and M. Latasa. 1997. Chlorophyll $a$ and pheopigments as tracers of labile organic carbon at the central equatorial Pacific seafloor. Geochim. Cosmochim. Acta 61: 4605-4619, doi:10.1016/ S0016-7037(97)00358-X

Sun, M. Y., R. C. Aller, AND C. LeE. 1991. Early diagenesis of chlorophyll $a$ in Long Island Sound sediments: A measure of carbon flux and particle reworking. J. Mar. Res. 49: 379-401, doi: $10.1357 / 002224091784995927$

, -, AND S. G. WAKEHAM. 2002. Effects of oxygen and redox oscillation on degradation of cell-associated lipids in surficial marine sediments. Geochim. Cosmochim. Acta 66: 2003-2012, doi:10.1016/S0016-7037(02)00830-X

Van Oevelen, D., M. Bergmann, K. Soetaert, E. Bauerfeind, C. Hasemann, M. Klages, I. Schewe, T. Soltwedel, and N. E. Budaeva. 2011a. Carbon flows in the benthic food web at the deep-sea observatory HAUSGARTEN (Fram Strait). Deep-Sea Res. I 58: 1069-1083, doi:10.1016/j.dsr.2011.08.002 , K. Soetaert, R. García, H. De Stigter, M. R. Cunha, A. Pusceddu, and R. Danovaro. 2011b. Canyon conditions impact carbon flows in food webs of three sections of the Nazaré canyon. Deep-Sea Res. II 58: 2461-2476, doi:10.1016/ j.dsr2.2011.04.009
J. J. Middelburg, P. M. J. Herman, L. Moodley, I. Hamels, T. Moens, And C. H. R. Heip. 2006. Carbon flows through a benthic food web: Integrating biomass, isotope and tracer data. J. Mar. Res. 64: 1-30, doi: $10.1357 / 002224006778189581$

K. Van Den Meersche, F. Meysman, K. Soetaert, J. J. Middelburg, And A. F. VéZina. 2010. Quantitative reconstruction of food webs using linear inverse models. Ecosystems 13: 32-45, doi:10.1007/s10021-009-9297-6

Vézina, A. F., AND T. Platt. 1988. Food web dynamics in the ocean. I. Best-estimates of flow networks using inverse methods. Mar. Ecol. Prog. Ser. 42: 269-287, doi:10.3354/meps042269

Wei, C. L., G. T. Rowe, E. Escobar-Briones, A. Boetius, T. Soltwedel, M. J. Caley, Y. Soliman, F. Huettmann, F. Y. Qu, Z. S. Yu, C. R. Pitcher, R. L. Haedrich, M. K. Wicksten, M. A. Rex, J. G. Baguley, J. Sharma, R. Danovaro, I. R. Macdonald, C. C. Nunnally, J. W. Deming, P. Montagna, M. LeVesque, J. M. Weslawski, M. Wlodarska-KowalczuK, B. S. Ingole, B. J. Bett, D. S. M. Billett, A. Yool, B. A. Bluhm, K. IkeN, and B. E. Narayanaswamy. 2010. Global patterns and predictions of seafloor biomass using random forests. PLoS One 5: e15323, doi:10.1371/journal.pone.0015323

WIESER, W. 1953. Die Beziehung zwischen Mundhöhlengestalt, Ernährungsweise und Vorkommen bei freilebenden marinen Nematoden. Eine skologisen-morphologische studie. Ark. Zool. 4: 439-484. [The relationship between mouth shape, diet and occurrence of free-living marine nematodes - an ecological-morphological study.]

Wigham, B. D., E. A. Galley, C. R. Smith, and P. A. Tyler. 2008. Inter-annual variability and potential for selectivity in the diets of deep-water Antarctic echinoderms. Deep-Sea Res. II 55: 2478-2490, doi:10.1016/j.dsr2.2008.06.007

, I. R. Hudson, D. S. M. Billett, And G. A. Wolff. 2003. Is long-term change in the abyssal Northeast Atlantic driven by qualitative changes in export flux? Evidence from selective feeding in deep-sea holothurians. Prog. Oceanogr. 59: 409 -441, doi:10.1016/j.pocean.2003.11.003

Witbaard, R., G. C. A. Duineveld, A. Kok, J. Van Der Weele, And E. M. Berghuis. 2001. The response of Oneirophanta mutabilis (Holothuroidea) to the seasonal deposition of phytopigments at the porcupine Abyssal Plain in the Northeast Atlantic. Prog. Oceanogr. 50: 423-441, doi:10.1016/ S0079-6611(01)00064-7

J. A. Van Der Weele, E. M. Berghuis, and J. P. REYss. 2000. The benthic response to the seasonal deposition of phytopigments at the Porcupine Abyssal Plain in the North East Atlantic. J. Sea Res. 43: 15-31, doi:10.1016/S13851101(99)00040-4

Witte, U., F. Wenzhofer, S. Sommer, A. Boetius, P. Heinz, N. Aberle, M. Sand, A. Cremer, W. R. Abraham, B. B. Jorgensen, And O. Pfannkuche. 2003. In situ experimental evidence of the fate of a phytodetritus pulse at the abyssal sea floor. Nature 424: 763-766, doi:10.1038/nature01799

Associate editor: Bo Thamdrup

Received: 10 July 2011 Accepted: 03 January 2012 Amended: 11 January 2012 